\title{
15 Crustaceans
}

\author{
Nicolas Rabet
}

\section{CONTENTS}

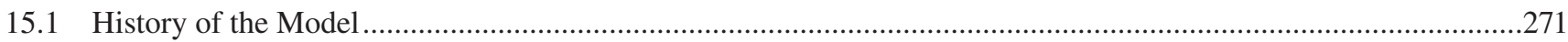

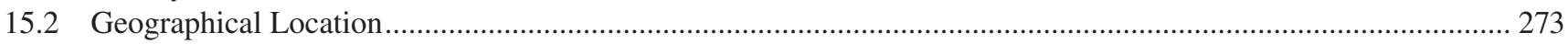

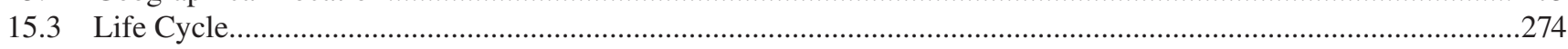

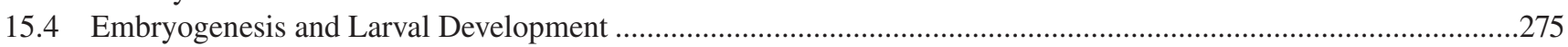

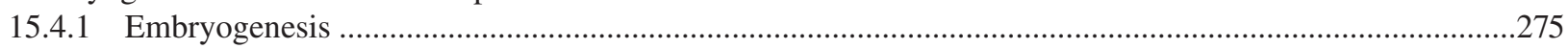

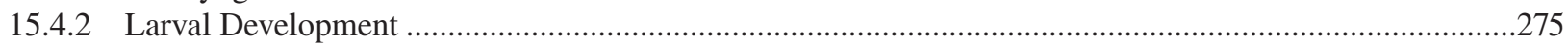

15.5 Anatomy

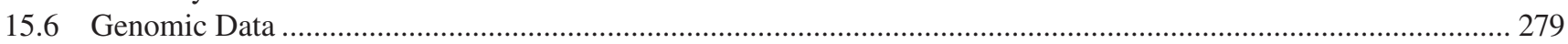

15.7 Functional Approaches: Tools for Molecular and Cellular Analyses.................................................................... 279

15.8 Challenging Questions Both in Academic and Applied Research ............................................................... 280

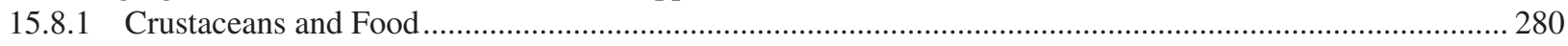

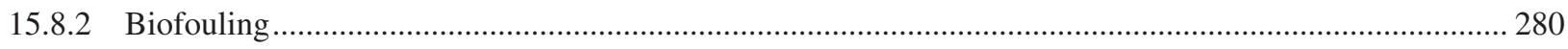

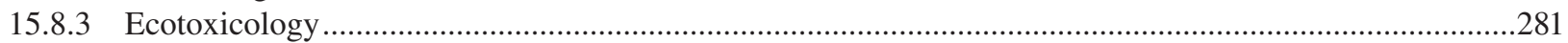

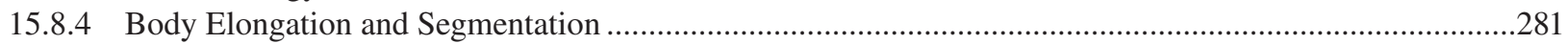

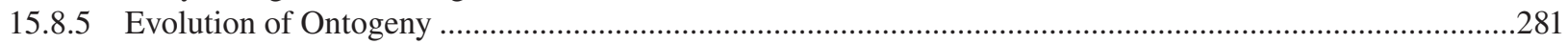

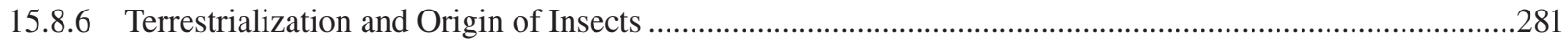

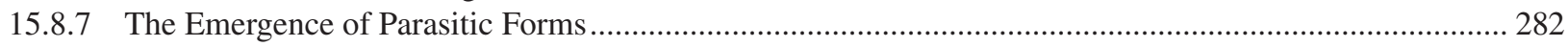

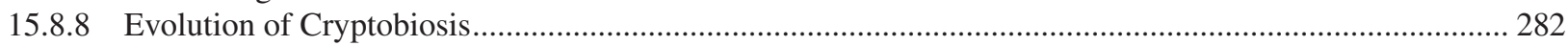

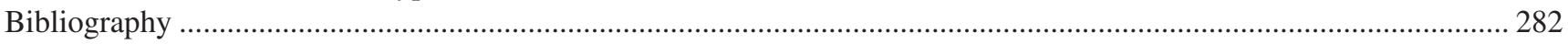

\subsection{HISTORY OF THE MODEL}

The word crustacea is derived from the Latin crusta, which means that the body is covered with a hard shell. The name Crustacea was first proposed by Brünnich (1772). Nevertheless, it took decades for it to establish itself, and the boundaries of the group have also changed significantly.

Today, crustaceans are a paraphyletic group, representing approximately 70,000 currently valid species distributed in nearly 1,000 families and in 9 major lineages (Remipedia, Cephalocarida, Malacostraca, Copepoda, Thecostraca, Branchiopoda, Mystacocarida, Branchiura and Ostracoda) (Ahyong et al. 2011; Regier et al. 2010).

Large crustaceans (malacostracans and barnaclesFigure 15.1) have always been known to humanity because they have been eaten for thousands of years (GutiérrezZugasti 2011; Zilhão et al. 2020). It is therefore quite logical that we can find crustaceans in old illustrations or in first classifications. In Aristotle's classification, some crustaceans were already listed under the name $\mu \alpha \lambda \alpha \kappa o ́ \sigma \tau \rho \alpha \kappa \alpha$ (malakostraka), which means animals with soft (malakós) shell (óstrakon) (Zucker 2005). Even if the word Malacostraca evokes a classic name of the current classification, for a very long time, most crustaceans were integrated among the insects without a specific group. Others were ignored or sometimes classified with other organisms. For example, Linnaeus (1758) classified some crustaceans in the order of
Aptera and recognized only three genera: Cancer with malacostracans and branchiopod anostracans; Monoculus with branchiura, other branchiopods, copepods, ostracods and two taxa including horseshoe crabs (which are now excluded from crustaceans); and Oniscus, regrouped malacostracan isopods. In addition, the cirripeds with genus Lepas was classified in the Vermes Testacea, while the parasitic copepods with the genus Lernaea were classified among the Vermes Mollusca.

Gradually, many species were described, and crustaceans were separated from insects on the basis of having a predominantly aquatic life, the presence of two pairs of antennae, biramate appendages and a nauplius larva. Like the morpho-anatomical diversity of the group, its classification has carried out numerous regroupings, and as such, many have been forgotten. The copepods, ostracods, branchiopods and cirripeds were gradually individualized and grouped in the entomostracans as opposed to the malacostracans (see Monod and Forest 1996). In the 20th century, new lineages of crustaceans were discovered, such as mystacocarids (Pennak and Zinn 1943), cephalocarids (Sanders 1955) and remipeds (Yager 1981). Bowman and Abele (1982) proposed a classification with six classes (Cephalocarida, Branchiopoda, Remipedia, Maxillopoda, Ostracoda and Malacostraca). The Maxillopoda grouped together the Mystacocarida, Cirripedia, Copepoda and Branchiura. 

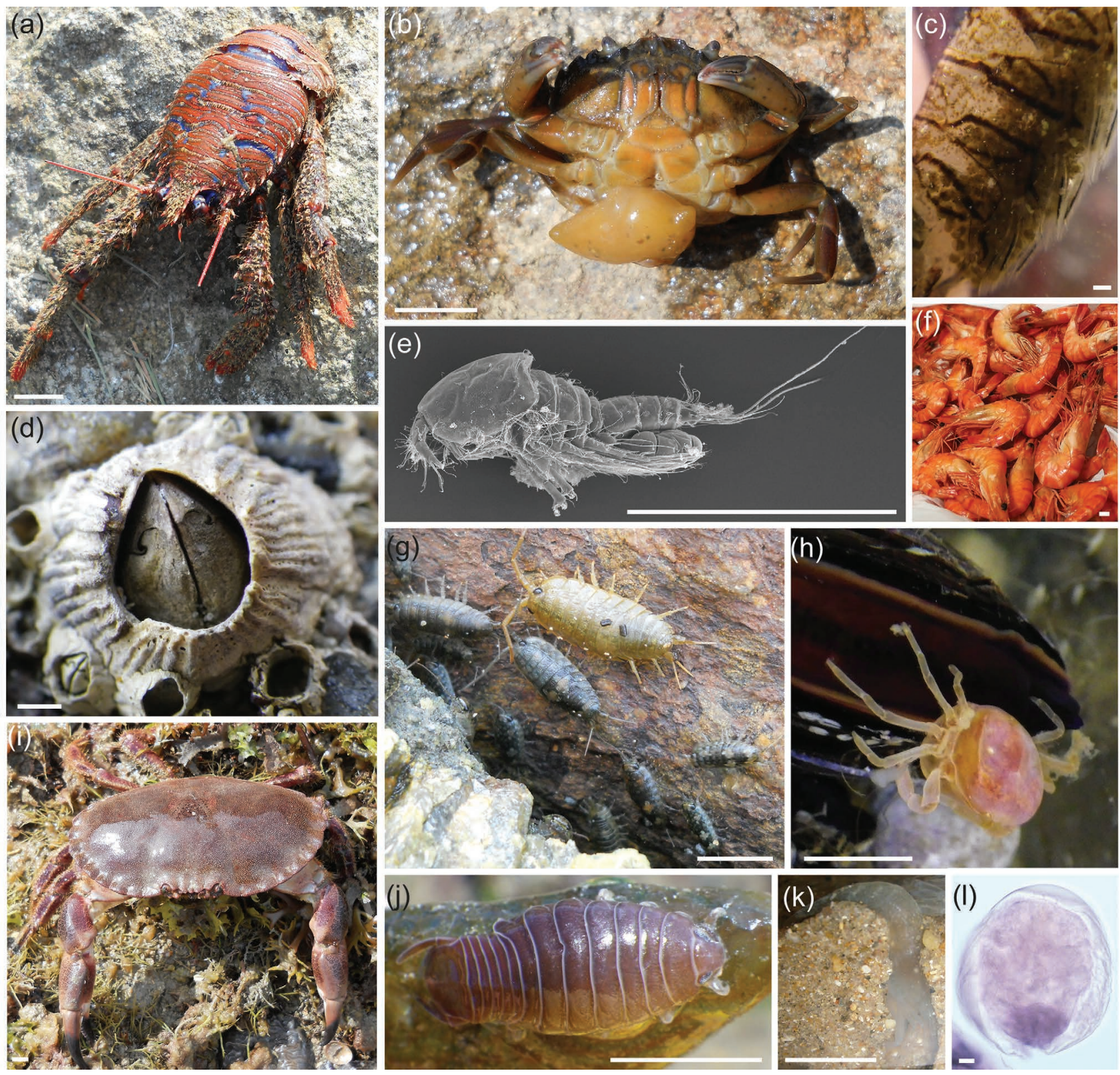

FIGURE 15.1 Marine crustacean (only Multicrustacea here) diversity illustrating morphological diversity, ecology and use. (a) Galathea strigosa (malacostracan); (b) Carcinus maenas (malacostracan) and Sacculina carcini (cirripeds); (c) Palaemon elegans eggs (malacostracan); (d) Semibalanus balanoides (barnacle); (e) Tigriopus brevicornis (copepod); (f) peneids in a market (malacostracan); (g) Ligia oceanica (malacostracan); (h) Pinnotheres pisum (malacostracan); (i) Cancer pagurus (malacostracan), Anilocra frontalis (malacostracan), Processa edulis (malacostraca), caudal gene expression in late embryo of Sacculina carcini (cirripeds). Scale bar: (a, b, $\mathrm{f}, \mathrm{g}, \mathrm{h}, \mathrm{i}, \mathrm{j}, \mathrm{k})=1 \mathrm{~cm} ;(\mathrm{c}, \mathrm{d}, \mathrm{e})=1 \mathrm{~mm} ;(\mathrm{l})=10 \mu \mathrm{m}$.

Since then, molecular phylogenies have completely revolutionized this classification.

The pentastomides, which are respiratory parasites of vertebrates that were previously classified in many groups such as Tardigrada, Annelida, Platyhelminthes and Nematoda and have a strange, elongated, worm-like body ringed with two pairs of hooks, were finally integrated into the Branchiura thanks to the $18 \mathrm{~S}$ gene sequencing comparison (Riley et al. 1978; Abele et al. 1989; Martin and Davis 2001; Lavrov et al. 2004).
Other analyses identified that the hexapods, previously believed to be close to crustaceans, were ultimately a lineage inside crustaceans (Regier et al. 2010) (Figure 15.2). As a result, crustaceans are not a monophyletic group but a paraphyletic group whose use remains practical to the extent that most animals are aquatic and share many ancestral characters. The name of the group incorporating hexapods among crustaceans is called the Pancrustacea, initially proposed by Zrzavý and Štys (1997), and some authors also use the name Tetraconata (Dohle 2001; Richter 2002). Several studies 


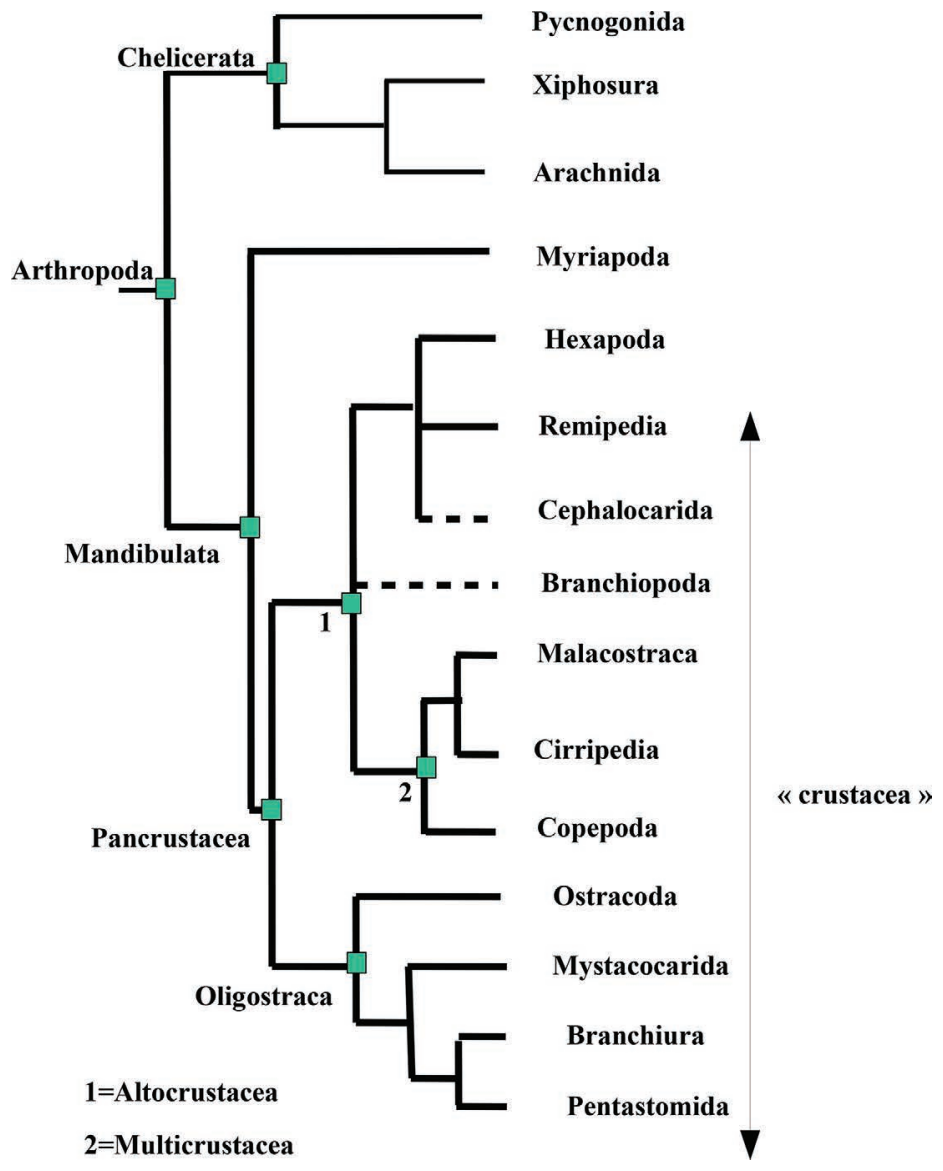

FIGURE 15.2 Phylogeny of Arthropoda. The dotted lines indicate that the position of these branches is uncertain. This figure clearly shows that crustaceans are paraphyletic. (From synthetic phylogeny built from Regier et al. 2010; Schwentner et al. 2017; Giribet and Edgecombe 2019.)

are now confirmed this important finding (Lee et al. 2013; Schwentner et al. 2017).

Another important change in crustacean phylogeny is that maxillopods are not monophyletic (Regier et al. 2005).

The relationships within the pancrustaceans are not entirely clear (Figure 15.1), mainly with respect to the position of branchiopods and cephalocarids (Schwentner et al. 2017; Giribet and Edgecombe 2019) (Figure 15.2). The earliest emergent group, called Oligostraca, contains Ostracoda, Branchiura, Tantulocarida, Mystacocarida and Pentastomida. It is the sister group of the rest of the Pancrustacea, called Altocrustacea and including Multicrustacea. The Multicrustacea contains the Malacostraca, Copepoda and Thecostraca (including cirripeds) (Figure 15.1). The position of Cephalocarida and Branchiopoda remains uncertain. All of these Pancrustacea lineages are very old, as evidenced by the fact that there were already malacostracans (Collette and Hagadorn 2010) and branchiopods (Waloszek 1993) present in the Cambrian era. Phylogenetic analysis has allowed scientists to confirm this (Regier et al. 2005), which implies that Pancrustacea has a truly ancient history with numerous lineages, a large part of which has probably disappeared.

In recent years, an important malacostracan amphipod model has been set up to study the development of crustaceans:
Parhyale hawaiensis (Browne et al. 2005). This model is important enough to constitute the subject of an entire part of the next chapter, and, as such, it will not be included in this chapter. Furthermore, in this chapter, some continental aquatic organisms will be considered with strictly marine animals for reasons of phylogenetic coherence and usage.

\subsection{GEOGRAPHICAL LOCATION}

Crustaceans are extremely diverse and widely distributed all over the world in all climates. The place of the marine environment for crustaceans is considerable both in terms of the number of species and in the lineages represented. They also have considerable ecological functions. The whole will therefore be difficult to summarize, and we will focus on only some specific adaptations.

Some crustacean species inhabit the deepest marine environments, such as the malacostracan amphipod Hirondellea gigas, which lives in the Mariana Trench, sometimes at depths of more than 10,000 meters. It consumes sunken wood coming from the surface thanks to particular enzymatic activities detected in the animal's gut (Kobayashi et al. 2012) and has also developed an aluminum hydroxide gel that covers its exoskeleton and that may be linked to life at 
great depths (Kobayashi et al. 2019). In the deep sea, there are also many crustaceans that live around hydrothermal vents. Many of them use chemo-autotrophic bacteria that provide nutrients to animals. This is particularly the case with the malacostracan Rimicaris exoculata on the MidAtlantic Ridge, which harbors bacterial communities in its branchial cavities (Petersen et al. 2010; Zbinden et al. 2020).

The diversity of crustaceans is also considerable in the tidal zone, with some species able to survive conditions that vary according to the water level variations. Some, like the malacostracan Carcinus maenas (Figure 15.1), are able to temporarily acclimatize to the absence of water and resist consequent variations in the environment. Native to Europe, this particularly well-adapted species has colonized many temperate sites around the world (Jensen et al. 2007). In pools of the highest tidal levels, we can often observe copepods Tigriopus (Figure 15.1), which are also impacted by high temperatures and consequent variations in salinity (Fraser 1936; Raisuddin et al. 2007). As in many groups, underwater caves have also been colonized and can be the refuge of many specialized and original organisms. Among these are remipeds, a group of blind, predatory crustaceans that inhabit anchialine underwater caves (Yager 1981; Koenemann et al. 2007). These are also the only venomous crustaceans (von Reumont et al. 2014). Among the meiofauna, there are many species of crustaceans such as copepods and ostracods living in sediments. It is also in this type of biotope that we can find the odd cephalocarids (Sanders 1955; Neiber et al. 2011).

Many crustaceans such as ostracods, malacostracans, copepods and branchiopods have also colonized brackish or fresh water. The border between the two environments is not necessarily clear, and after passing through fresh water, some organisms then return to the marine environment, such as the marine cladocerans that represent few species but have a global distribution (Durbin et al. 2008). The hypersaline environments that form in coastal areas or sometimes in the middle of continents have also been colonized by crustaceans, in particular ostracods and copepods. However, the champion of resistance is unmistakably the branchiopod Artemia, which can survive in supersaturated salty environments up to $340 \mathrm{~g} / 1$ (Gajardo and Beardmore 2012).

As it is sometimes difficult to dissociate marine crustaceans from freshwater or hypersaline crustaceans in an evolutionary way, they will be partially integrated in this chapter.

There have also been several colonizations by pancrustaceans of terrestrial environments such as hexapods or woodlice, but there are also terrestrial lineages in the adult state whose larvae are completely marine, as is the case for many terrestrial crabs or terrestrial hermit crabs. In this category, there are the largest land-living arthropods, like the coconut crab (Birgus latro) (Krieger et al. 2010). This hybrid lifestyle, which is also found in amphidromic crustaceans (living partially in freshwater and seawater), allows these animals to exploit the dispersive abilities of marine planktonic life and to colonize more or less isolated continental environments (Bauer 2013).

Crustaceans are also an essential component in the plankton of all seas. Some species live their entire life cycle as plankton and play a major ecological role (copepods, euphausiids). However, for many species, the passage through plankton is transient as part of a marine bentho-pelagic species or many terrestrial or freshwater crustaceans.

Crustaceans are so ubiquitous, it is almost impossible to study the aquatic environment without finding one!

\subsection{LIFE CYCLE}

In crustaceans, the life cycle presents extremely variable modalities. The majority of species are gonochoric with separate sexes, but there are cases of parthenogenesis in the brine shrimp Artemia (Bowen et al. 1978) and many freshwater and terrestrial species, probably due to the dispersive advantage (Scholtz et al. 2003; Kawai et al. 2009). There are cases of simultaneous hermaphroditism (both type of gonads are present simultaneously) in remipeds (Neiber et al. 2011), cephalocarids (Addis et al. 2012), cirripeds (Charnov 1987) and some branchiopods (Scanabissi and Mondini 2002; Weeks et al. 2014). Sequential hermaphrodism (change of sex during the life) is more observed in malacostracans (Benvenuto and Weeks 2020).

The mating modalities are also extremely varied in crustaceans and result in very different appendicular adaptations. The most original is undoubtedly the presence of a long penis in the barnacles which is always fixed and which compensates for the low mobility of the gametes (Barazandeh et al. 2013).

In most species, the mother will protect her offspring to allow the release of larvae. However, most calanoid copepods, euphausiids and dendrobranchiate decapods (Penaeoidea and Sergestoidea) shed their eggs into the water column (Lindley 1997).

In many crustaceans, the instability of trophic resources and living conditions has favored the development of a strategy of slowing down or stopping development during the deficit season (Alekseev and Starobogatov 1996). In this case, the eggs are laid and start diapausis. There are also resistance forms in anhydrobiosis or cryptobiosis (absence of metabolism with dehydration) (Fryer 1996; Alekseev and Starobogatov 1996). This innovation sometimes concerns the larvae, as in the copepod Metacyclops minutus (Maier 1992), but more often, it is the embryo that enters a state of suspended life. The embryo can be enveloped by different layers of varying natures and becomes resistant to drying out or freezing. In this form, we speak of a resting egg (also called a "duration egg" or "cyst"), and, when conditions are favorable, development resumes, leading to the release of a larva or an aquatic juvenile (Brendonck 2008).

In a group of malacostracan shrimps of the Alpheidae family, the existence of eusocial behavior has recently been reported, such as is found in insects and vertebrates (Duffy 1996).

In many species, the larvae released after hatching become planktonic. During this planktonic phase, the animals grow and disperse. At the end of the larval stages, there are animals whose adults remain in the plankton (many 
copepods, euphausiids) and others which emerge, most often becoming benthic. Sometimes the modifications are brutal and called metamorphosis for sessile animals, like in barnacles (Høeg and Møller 2006; Maruzzo et al. 2012). In this group, the transformation will result in a completely fixed animal. The choice of the fixation site is therefore essential for the survival of the individual, because it will subsequently have to withstand the conditions imposed by the environment. Recruitment is carried out by olfaction through antenna 1 of the substrate (Figure 15.4c). The bacterial film can be detected and, depending on its composition, induce the attachment of the cyprid larva (Rajitha et al. 2020). The presence of congeners due to the release of pheromones from adults that are not always necessarily from the same species is also an essential factor for fixation (Abramova et al. 2019). After an exploration phase using the attachment discs located at the end of the antenna 1, the final fixation is achieved by the deposition of a cement comprised of lipids and phosphoproteins (Liang et al. 2019).

In parasitic crustaceans, the life cycle is often highly modified. The most extensive parasitic life transformations are found in pentastomids, copepods and cirripeds. Adults are often very divergent from their non-parasitic parents, to the point that association with a taxonomic group has only been possible by studying the larval stages like for the cirriped Rhizocephala (Thompson 1836) (Figure 15.1b) or more recently by molecular data, like for the pentastomids (Abele et al. 1989). Rhizocephalic cirripeds are parasites characterized by considerable morphological transformations but also considerable modifications of their life cycle. The female larva will transform into a kentrogon, a kind of injection system that allows a few cells to invade the host, which will develop into a network resembling roots and allowing it to feed. The male larvae transform into trichogons and settle as hyperparasites on the females. The mature parasite profoundly modifies the physiology of the organism by feminizing it and blocking the molt (Delage 1884; Høeg and Lützen 1995).

\subsection{EMBRYOGENESIS AND LARVAL DEVELOPMENT}

In crustaceans, embryonic development is very variable depending on the groups or species. In the case of direct development, all of the ontogenetic stages lead to the release of a juvenile. In the case of the release of a larva, the steps missing to obtain a juvenile will be performed by larval development. The predominance of one or the other is therefore variable depending on phylogenetic history and ecological context, and both must be studied to understand the ontogeny of a species. In the case of the release of a larva, the essential difference with the equivalent embryonic stages in another species is at least the acquisition of mobility and sometimes early nutrition.

The modalities of embryonic development are extremely variable in crustaceans, and it is not possible to present them all here. We will use Chapter 16 as a reference for malacostracans, and here we will mainly develop the Artemia model, which is the organism with the best-studied anamorphic development.

\subsubsection{EMBRYOGENESIS}

The embryonic development of Artemia has been described by Benesch (1969) and Rosowski et al. (1997). After fertilization, the embryo forms a gastrula. Postgastrulean development until nauplius hatching occurs without any cell division (Olson and Clegg 1978). The 5,000 cells present in the gastrula organize and differentiate the head structures, including the three pairs of appendages and the salt gland. The rest of the head and the post-cephalic structures are formed from the remaining 2,000 cells. The posterior region of the embryo then takes the shape of a cone, and the ectoderm of this post-mandibular region takes on the appearance of a grid with long columns of cells arranged in parallel along the antero-posterior axis. The posterior region thus resembles that of other crustaceans, but in this case, it results from a phenomenon of reorganization. Upon hatching, the cells that compose the larva are small and diploid in the posterior region, while the cephalic elements (salt gland and appendages) are constituted by polyploid cells (Olson and Clegg 1978). At the gastrula stage, the embryo can go into cryptobiosis, and the dormant state is stabilized by the P26 protein (Malitan et al. 2019). In this case, the outer layers (shell) of the embryo are produced by the shell glands of the female (Morris and Afzelius 1967; Anderson 1970; Garreau de Loubresse 1974) and allow the protection of the embryo against variations in the environment. A shell gland specifically expressed gene (SGEG) has been found to be involved in egg shell formation. Lacking SGEG protein (by RNA interference) caused the eggs' shell to become translucent and induce a defective resting egg (Liu et al. 2009).

\subsubsection{Larval Development}

The emblematic larva of crustaceans is undoubtedly the nauplius larva (Figure 15.3). The first observation of nauplius dates back to the emergence of the first microscopes and was made by Antonie van Leeuwenhoek in 1699 on Cyclops copepods (Gurney 1942). Since then, it is found in many lineages of Pancrustacea and is probably one of the synapomorphies of this group (Regier et al. 2010). It is an externally unsegmented oligomeric head larva with three pairs of appendages and one pair of eyes corresponding to the most anterior part of the head (Figure 15.3a-c) (Dahms 2000). It shows similarities with the protonymphon larva of the pycnogonids, and the presence of homologous appendages (Figure 15.3d) suggests that this type of larva is possibly ancestral (Alexeeva et al. 2017). In crustaceans, the nauplius is the earliest larval stage observed.

The larval development of Artemia has been studied in detail (Anderson 1967; Benesch 1969; Schrehardt 1987). The development of the anterior structures leads to the replacement of structures composed of polyploid cells by the definitive adult organs, developed from diploid precursor 

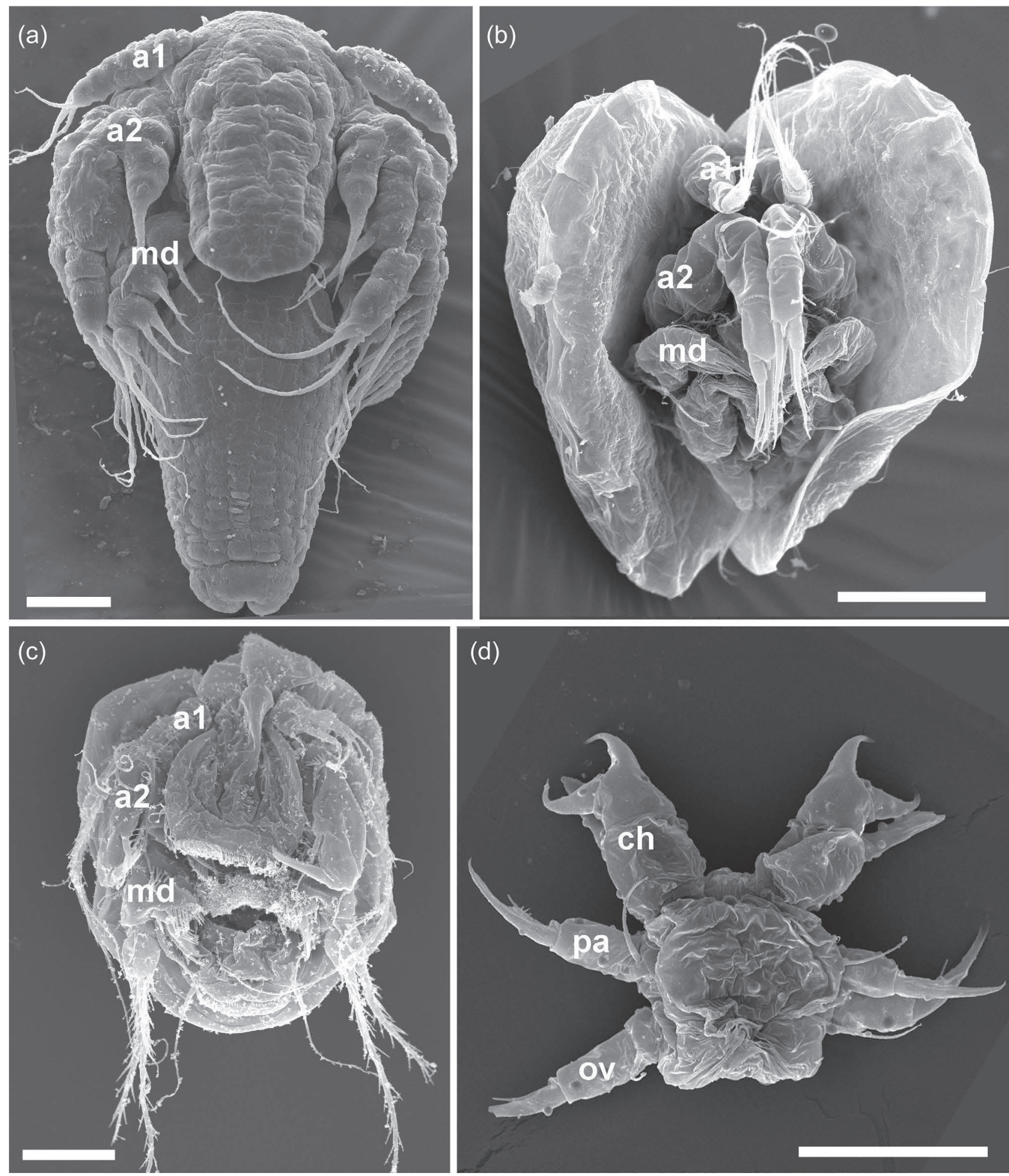

FIGURE 15.3 Some "head larvae" of different arthropods. The nauplius larva (a, b, c) is a synapomorphy of Pancrustacea. It closely resembles the protonymphon larva of sea spiders (d). (a) Artemia franciscana (branchiopods); (b) Heterocypris incongruens (ostracods); (c) Tigriopus brevicornis (copepods); (d) Endeis sp. (pycnogonids). a1: antenna 1, a2: antenna 2, md: mandible, ch: cheliphore, pa: palp, ov: oviger. The scale bar measures $50 \mu \mathrm{m}$ for $(\mathrm{a}, \mathrm{b}, \mathrm{c})$ and $10 \mu \mathrm{m}$ for (d).

cells remaining within the cephalic structures (Olson and Clegg 1978).

In the posterior region of the larva, in front of the telson, a "morphogenetic differentiation area" is established. Along with this expression, the arrangement of the cells changes, forming rows of cells perpendicular to the anteroposterior axis (Figure 15.3a). In this same area, the intersegmental boundaries then appear by constriction of the ectoderm 
around the body, first creating the parasegments, then the final segments (Prpic 2008). We can therefore observe, in the same Artemia larva, a whole series of levels of development of the segments and their appendages (Figures 15.4, 15.5). When new appendages appear in the nauplius, these stages can be called metanauplius (Figure 15.4).

In the posterior region of the larva, in front of the telson, the segments appear and then gradually differentiate, making it possible to distinguish, at a given stage and in an arbitrary fashion, several levels of differentiation located from back to front as follows (Figures 15.4, 15.5):

- Initial cell proliferation;

- Cellular and genetic segmentation program;

- Segmental morphogenesis;

- Morphogenesis of the appendages.
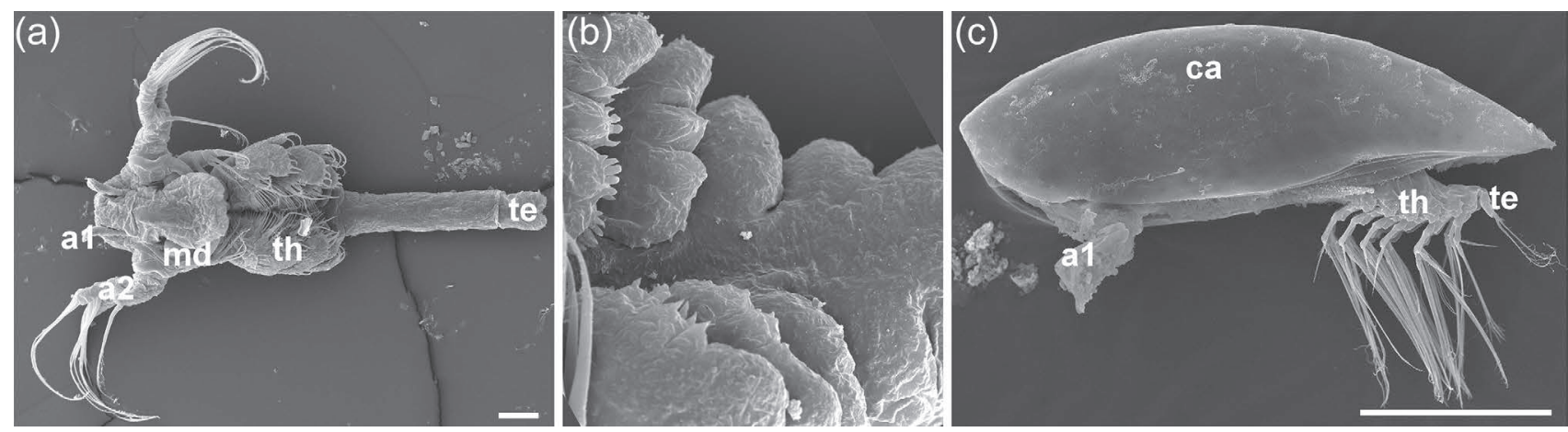

FIGURE 15.4 Larval development. (a, b) Metanauplius (late nauplius) stage of Artemia franciscana showing the levels of segment differentiation according to their position in the anteroposterior axis. (b) zoom of (a) at the level. (c) Cyprid stage of Sacculina carcini. This cyprid stage is a synapomorphy of Cirripeds and probably Thecostraceans. a1: antenna 1, a2: antenna 2, md: mandible, th: thorax, te: telson, ca: carapace. Scale bar: $100 \mu \mathrm{m}$.
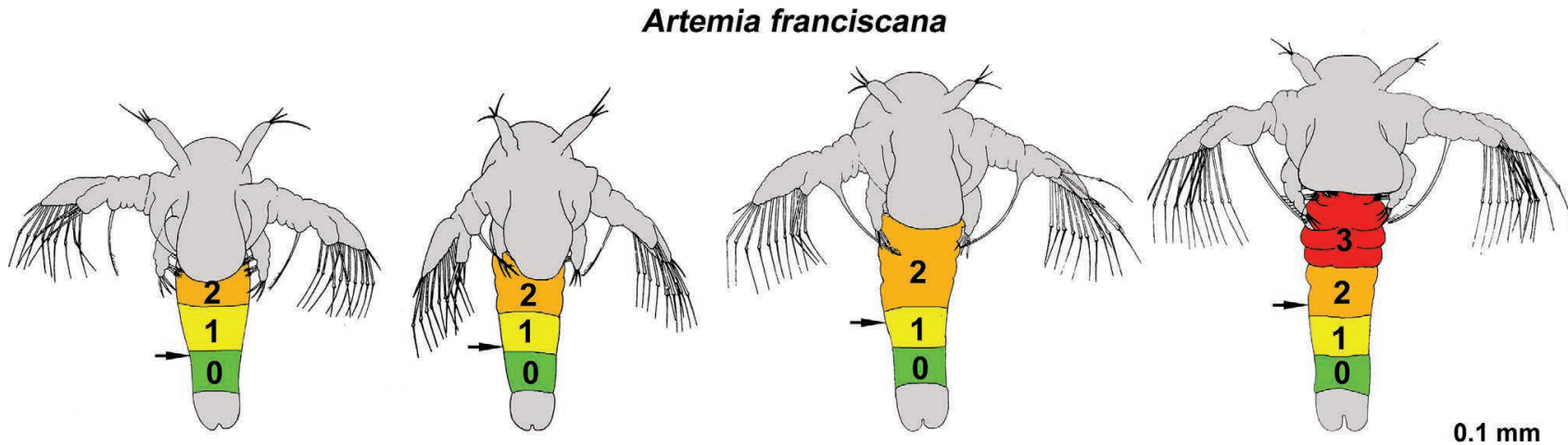

\section{Sacculina carcini}

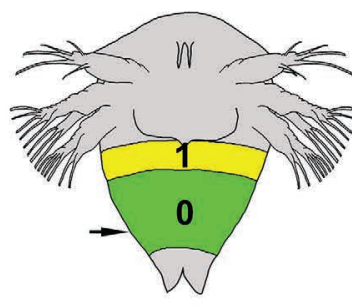

Initial cell proliferation

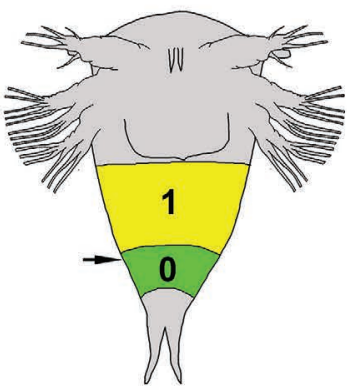

Early expression of segmental genes

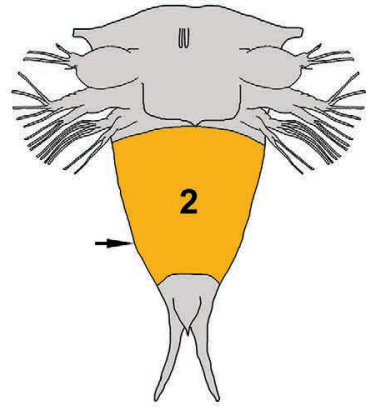

2 Segmental morphogenesis

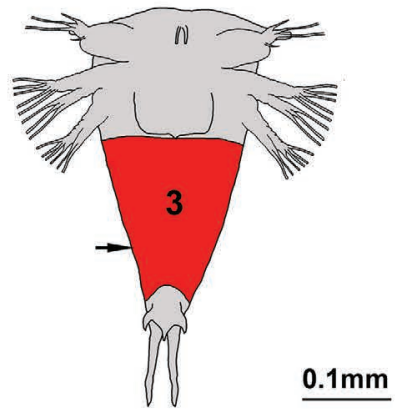

Appendicular morphogenesis

FIGURE 15.5 Comparison of the early larval development of Artemia franciscana and Sacculina carcini. Artemia has an anamorphous development with progressive elongation of the body. Sacculina, although producing nauplius, has an altered development showing synchronization of morphogenesis. The arrow indicates the position of a region of a specific thoracic segment during larval development. (The stage is redrawn after Collis and Walker 1994; Anderson 1967; Schrehardt 1987. The identifi cation of the territories is synthesized after Schrehardt 1987; Manzanares et al. 1993; Copf et al. 2003; Gibert et al. 2000; Rabet et al. 2001; Trédez 2016.) 
This type of development is found in many lineages of crustaceans: Cephalocarida, Remipedia, Branchiopoda, Branchiura, Ostracoda, Copepoda, Mystacocarida, Malacostraca, Dendrobranchiata and Euphausiacea (Martin et al. 2014).

In cirripeds, nauplius are morphologically quite similar to the others, but larval development leads to a fairly synchronous intracuticular construction of thoracic segments that deviate clearly from the anamorphic model (see Figure 15.5) (Trédez et al. 2016). In addition, in this group, larval development leads to a typical stage called cypris, which precedes a metamorphosis for a fixed life (Høeg and Møller 2006; Maruzzo et al. 2012) (Figure 15.4).

In malacostracans, there are several direct or pseudo-direct developments, but in many groups, the hatching reaches a zoea-like larva stage (Jirikowski et al. 2015). This stage also appears in malacostracans producing a nauplius. The larva is characterized by a complete or nearly complete body segment number. It has functional thoracic appendages and most of the time has two eyes (Anger 2001). These generally planktonic larvae have specific names depending on their morphology and belong to different groups of malacostracans (protozoea, metazoea, mysis or phyllosoma) (Anger 2001)

In many malacostracans, an embryo with a naupliuslike form appears transiently in the embryo reminiscent of ancestral development (Scholtz 2002; Jirikowski et al. 2013; Jirikowski et al. 2015). Spawning at sea can be the subject of animal migration: Christmas Island has seen crab invasions due to a mass migration of animals during the egg-laying season (Adamczewska and Morris 2001).

\subsection{ANATOMY}

The morpho-anatomical diversity is quite exceptional (see Figure 15.1 only for Multicrustacea). The majority of animals have bilateral symmetry and a metameric organism. The head has an ocular region and appendages that are in sequence: two pairs of antennae (A1 and A2), the mandibles and two pairs of maxillae (M1 and M2). Both pairs of antennae and maxillae are characteristic of crustaceans (Scholtz and Edgecombe 2006). The head is made up of six segments (Zrzavý and Štys 1997). The posterior part of the body is terminated by the telson bearing the anus and sometimes with caudal furca (McLaughlin 1980). Between the head and the telson, the segments can be similar to each other and thus form a trunk in remipeds (Yager 1981; Neiber 2011), but more often, they are different and thus grouped into functional and morphological groups called tagmes. These body regions can therefore be specialized in locomotion, reproduction, respiration and nutrition functions and are generically called the thorax and the abdomen. In malacostracans, they can be called the pereion and the pleon (Mayrat and Saint Laurent 1996). It is quite possible that the tagmes are not homologous in the different groups and that the regroupings took place from an untagmatized ancestor (Averof and Akam 1995). Sometimes the head is fused with the thorax to form a cephalothorax or prosoma, with the addition of appendages associated with the function of food intake, the maxillipeds especially in copepods, some malacostracans and remipeds (Averof and Patel 1997; Yager 1981).

The number of body segments is often stable within a group, such as the hexapods. Thus, the Malacostraca has six cephalic segments, eight thoracic segments and six abdominal segments, with the exception of the leptostracans, which have seven. The different groups formerly classified in the Maxillopoda like the copepods, branchiurans, ostracods and the cirripeds have seven thoracic segments and four abdominal segments (Richter 2002).

On the other hand, in other lineages such as branchiopods or remipeds, the number of body segments can vary. For Triops (branchiopods), the number of segments changes within a population (Korn and Hundsdoerfer 2016).

The carapace is a structure that emerges from the posterior part of the head and covers part or all of the body. It is found in many groups of crustaceans with varying forms, and the hypothesis of its ancestrality in the line has been made (Calman 1909). The functions of the carapace are variable: in addition to a protective aspect of organisms, the carapace can have other functions such as having a role in hydrodynamics, protection of eggs, respiration and sometimes even in nutrition (Watling and Thiel 2013).

In cirripeds, the carapace turns into shell plates during metamorphosis (Watling and Thiel 2013). The cuticle of many crustaceans is associated with calcium carbonate, except in the plates of a small barnacle group, where it is composed of calcium phosphate (Lowenstam and Weiner 1992), a compound also found in the mandible of many malacostracans (Bentov et al. 2016).

In pancrustaceans, the appendages are ancestrally biramous. There is an outer branch called the expopodite and an inner branch called the endopodite. Additionally, there are expansions on the external (epipodite) or internal (endite) side. The function of these appendages is multiple and shows great flexibility with significant adaptive diversity (Boxshall 2004). In malacostraceans, there are appendages that can be transformed into a weapon, in particular in the form of a pincer. In some alpheid malacostraceans and stomatopods, the extreme speed of specialized appendages creates cavitation causing localized phenomena of extreme violence (Patek and Caldwell 2005; Lohse et al. 2001).

The appendages can even be leafy and have the functions of locomotion, nutrition and simultaneous respiration in branchiopods and in malacostracan leptostracans (Pabst and Scholtz 2009).

The morpho-anatomy of the body is particularly affected in the case of profound modification of the way of life and in particular when free life is abandoned. The fixed way of life in cirripeds leads to a profound modification of the animals, since the animal is fixed by the head and the locomotor appendages have been transformed into appendages used to capture prey (Høeg and Møller 2006) (Figures 15.1d, 15.7). Parasitic life also causes profound morpho-anatomical modification with the appearance of hooks or suction cups or even the introduction of ink or some sort of roots in some cases (Lavrov et al. 2004; Høeg and Lützen 1995) (Figure 15.1b). 


\subsection{GENOMIC DATA}

New sequencing methods (NGS) make it possible to obtain DNA fragments at low cost to reconstruct genome fragments or complete genomes. With a bar-coding approach by PCR and transcriptome sequencing, we are able to obtain data for phylogenetic analyses essential to further understanding crustaceans and to proposing evolutionary scenarios. The mitochondrial genome has been obtained from many species, and there are rearrangements that may be useful in identifying or confirming delicate parts of the phylogeny. This is, for example, the case of a reorganization observed in the pentastomides that we found also in the branchiurans (Lavrov et al. 2004).

The first complete crustacean genome published is that of Daphnia pulex (Colbourne et al. 2011), but currently the number of sequenced genomes is increasing rapidly. However, the choice of crustacean models mainly concerns freshwater or brackish water models and few truly marine animals (Table 15.1).

There is a strong variation in the sizes of genomes in crustaceans. The smallest appears to be the branchiopod Lepidurus, with a little less than $0.11 \mathrm{~Gb}$ (Savojardo et al. 2019), and the largest, the arctic malacostracan Ampelisca macrocephala, seems to be the biggest with about $63.2 \mathrm{~Gb}$ (Rees et al. 2007), or almost 600 times bigger.

It would seem that crustaceans living in constant and cold environments would have genomes larger than others (Alfsnes et al. 2017). Similarly, the control region of the mitogenome in polar copepods of the genus Calanus is known to be the longest of the crustaceans (Weydmann et al. 2017).

\subsection{FUNCTIONAL APPROACHES: TOOLS FOR MOLECULAR AND CELLULAR ANALYSES}

Paryhale hawaiensis is arguably the richest and most tooled model today in crustaceans and will not be presented here (see Chapter 16). Historically, early work on larval gene expression used immunohisto-chemistry and in situ hybridization performed in Artemia through sonication processes to make the cuticle permeable (Manzanares et al. 1993; Averof and Akam 1995). This method has been improved by chemical permeabilization (Blin et al. 2003; Copf et al. 2003). RNAi has been successfully tested on Artemia (Copf et al. 2004) and on Litopenaeus vannamei (Robalino et al. 2004).

The intense development of crustacean cultures for food production was quickly accompanied by the proliferation of numerous studies on farming models. Studies have been conducted on genes related to biomineralization and genes related to RNAi machinery, but many of the studies are focused on reproductive mechanisms to optimize reproduction such as encoding genes for eyestalk neuropeptides, gene receptor-encoding genes and genes related to sexual differentiation (Sagi et al. 2013).

In addition, many diseases have developed due to the high concentrations of animals, the impact of which remains a major concern for aquaculture maintenance (Stentiford et al. 2012).

Thus, RNAi provides modern and promising tools to treat shrimp that can be affected by nearly 20 different viruses (Krishnan et al. 2009; Escobedo-Bonilla 2011; Gong and Zhang 2021).

\section{TABLE 15.1 \\ List of Complete Genomes Published}

\begin{tabular}{|c|c|c|c|c|}
\hline Species Name & Group & Habitat & Size in Gb & Publication \\
\hline Acartia tonsa & Copepoda & Marine & 2.5 & Jørgensen et al. (2019b) \\
\hline Amphibalanus amphitrite & Cirrepedia & Marine & 0.481 & Kim et al. (2019) \\
\hline Apocyclops royi & Copepoda & Fresh to brackish water & 0.45 & Jørgensen et al. (2019a) \\
\hline Armadillidium vulgare & Malacostraca & Terrestrial & 1.72 & Chebbi et al. (2019) \\
\hline Daphnia pulex & Branchiopoda & Fresh water & 0.2 & Colbourne et al. (2011) \\
\hline Daphnia magma & Branchiopoda & Fresh water & 0.123 & Lee et al. (2019) \\
\hline Diaphanosoma celebensis & Branchiopoda & Brackish water & 2.56 & Kim et al. (2021) \\
\hline Eriocheir sinensis & Malacostraca & Fresh water to marine & 1.66 & Song et al. (2016) \\
\hline Eulimnadia texana & Branchiopoda & Fresh water & 0.12 & Baldwin-Brown et al. (2017) \\
\hline Lepidurus apus & Branchiopoda & Fresh water & 0.1075 & Savojardo et al. (2019) \\
\hline Lepidurus articus & Branchiopoda & Fresh water & 0.1075 & Savojardo et al. (2019) \\
\hline Macrobrachium nipponense & Malacostraca & Fresh water & 4.5 & Jin et al. (2021) \\
\hline Neocaridina denticulata & Malacostraca & Fresh water & 3.2 & Kenny et al. (2014) \\
\hline Parhyale hawaiensis & Malacostraca & Marine & 3.6 & Kao et al. (2016) \\
\hline Portunus trituberculatus & Malacostraca & Marine & 1.0 & Tang et al. (2020) \\
\hline Procambarus clarkii & Malacostraca & Fresh water & 8.5 & Shi et al. (2018) \\
\hline Procambarus virginalis & Malacostraca & Fresh water & 3.5 & Gutekunst et al. (2018) \\
\hline Tigriopus californicus & Copepoda & Marine & 0.190 & Barreto et al. (2018) \\
\hline Tigriopus japonicus & Copepoda & Marine & 0.197 & Jeong et al. (2020) \\
\hline Tigriopus kingsejongensis & Copepoda & Marine & 0.295 & Kang et al. (2017) \\
\hline Trinorchestia longiramus & Malacostraca & Semi-terrestrial & 0.89 & Patra et al. (2020) \\
\hline
\end{tabular}


Transgenesis was successfully performed on the freshwater branchiopod Daphnia magma (Kato et al. 2012).

\subsection{CHALLENGING QUESTIONS BOTH IN ACADEMIC AND APPLIED RESEARCH}

The diversity of crustaceans is such that we can ask many questions about the evolution of the development of these animals. We will start by discussing some aspects of research applied to the development of crustaceans, and then we will see some aspects of more fundamental research.

\subsubsection{Crustaceans and Food}

Crustaceans have always been a source of food for humanity, even concerning pre-modern human species, as evidence suggests Neanderthals ate them, too (Zilhão et al. 2020). Crustacean species consumed by humans are generally large in size and relatively abundant. The vast majority are malacostracans and among them mainly decapods. More occasionally, large barnacles are also consumed. In 2018, the marine capture production by fisheries was around 6 million tons per year in seawater and 0.45 million tons per year in freshwater. The farming of crustaceans in aquaculture represents 9.4 million tons per year (USD 69.3 billion) (FAO 2020). Crustacean farming is therefore an important source of food and is essentially based on controlling the development cycle of species, in particular the production of larvae or juveniles. The first breeding operations in Southeast Asia or America consisted of taking post-larvae and juveniles of malacostracan penaeid prawns in brackish water ponds in order to obtain extensive breeding. Indonesian "tambaks" are well-known examples of these traditional practices (Laubier and Laubier 1993; Escobedo-Bonilla 2011).

The development of the study of larval stages from the 19th century onward gradually made it possible to control the cycle of a species of interest, of which, in some cases, stocks were rapidly declining. The first step consisted of restocking, that is to say the release of larvae, which was practiced by the end of the 19th century. The results of the first lobster releases are not obvious (Laubier and Laubier 1993), but improvements in crustacean farming and behavioral testing may allow improving this practice (Carere et al. 2015).

Hudinaga (1942) completed the life cycle of Penaeus japonicus by identifying foods suitable for different stages. Panouse (1943) began to understand the hormonal regulation of Leander serratus reproduction allowing better control of shrimp reproduction. Hudinaga's work in the beginning of the 1960s enabled the first ton production of Penaeus japonicus reared in captivity. Production started to increase very significantly in the beginning of the 1980 s (Laubier and Laubier 1993).

The resting eggs of the brine shrimp Artemia give aquaculture institutions the ability to obtain larvae at any desired time, since the cryptobiosis can be stopped by putting them back in water under appropriate conditions (Van Stappen et al. 2019) (Figure 15.6). This ability is combined with the fact that since Seale (1933), it is known that these larvae are good food for young fish. This organism is not strictly marine but lives and develops perfectly in sea water and can therefore serve as living food for many marine organisms at key stages of their development, forming a kind of artificial marine plankton. The production of Artemia larvae is suitable for $85 \%$ of the marine animals bred (Sorgeloos 1980).

It is therefore also essential for the aquarium hobbyists or the breeding of animals for scientific purposes, which is the case for many of our development models such as cnidarians (Lechable et al. 2020), many marine fishes (Madhu et al. 2012) or freshwater fish (Dabrowski and Miller 2018; Shima and Mitani 2004). Artemia are also used as food for other crustaceans like barnacles (Desai et al. 2006; Jonsson et al. 2018) or many malacostracans (Sorgeloos 1980).

\subsubsection{BIOFOULING}

Organism colonization called biofouling affects ships, buoys, pontoons, offshore structures and many other human marine constructions (Figure 15.7). Issues include increased costs, reduced speed, environmental concerns, corrosion and safety hazards (Bixler and Bhushan 2012). Antifouling methods currently employed, ranging from coatings to cleaning techniques, have a significant cost (Bixler and Bhushan 2012). Barnacles are among the most important fouling organisms in the marine environment (Abramova et al. 2019). Recruitment of these animals around the cyprid/juvenile

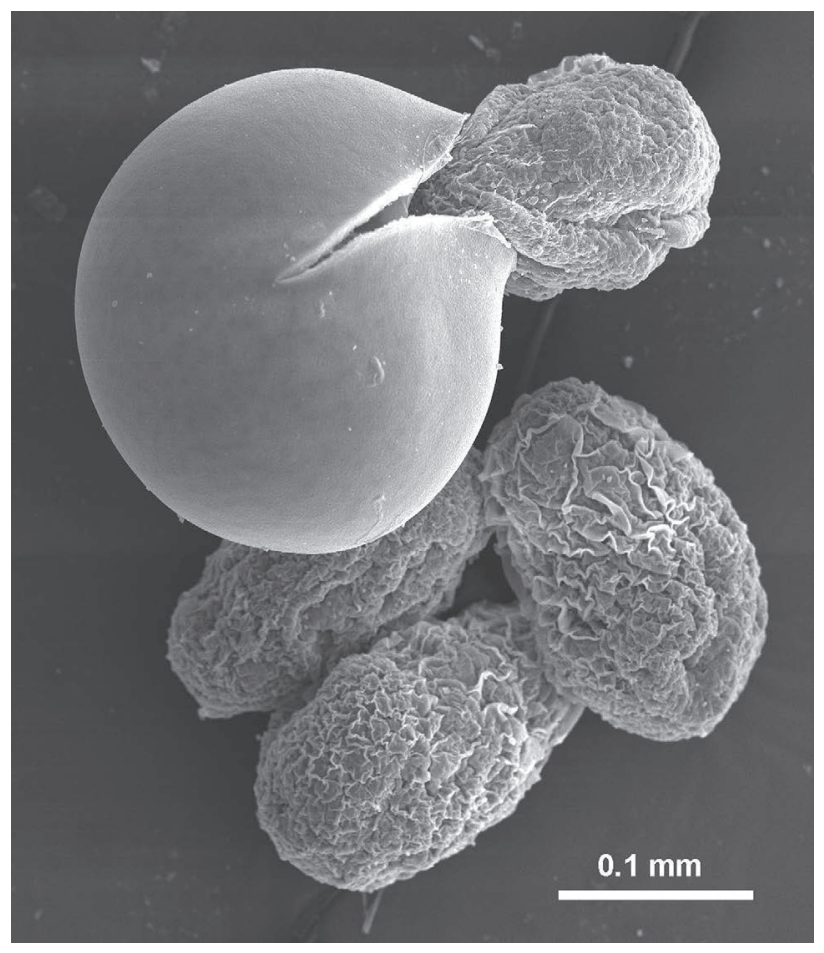

FIGURE 15.6 Artemia hatching. Resting egg and pre-hatching larvae of Artemia franciscana after re-filling. The nauplius larva still remains surrounded by the membrane and will soon swim. Hatch control is the basis of its success in marine aquaculture and fundamental research. 


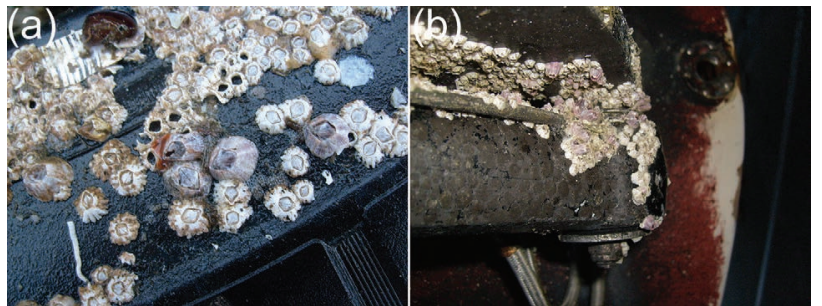

FIGURE 15.7 Biofouling by the barnacles Amphibanalus amphitrite and Elminius modestus in the port area of Saint Malo (North Brittany). (a) Tire used as port fender, (b) Underside of a boat needing cleaning.

stages is the key step in this problem, since fixation is definitive. Understanding the different stages of development from prospecting for the substrate to fixation through metamorphosis is therefore essential to prevent colonization. One strategy is to develop surfaces that are actively rejected by cyprids during the initial stages of the surface exploration, thus preventing attachment (Abramova et al. 2019). A more unexpected aspect of biofouling is that it can also serve as an indicator of the history of floating objects. Thus, the ambient temperature of the aircraft debris of the Boeing 777-200ER aircraft operated by Malaysian Airlines as MH370 was estimated from the biochemical analysis of the barnacles attached to the flaperon (Nesterov 2018).

\subsubsection{EсоToxicology}

Small crustaceans are widely used in ecotoxicology because they represent an important link as a primary or even secondary consumer between primary producers and consumers of higher trophic levels, such as fish, for which they are an important food.

From the 1980s, Artemia was used very frequently as a standardized marine ecotoxicology test (Persoone and Wells 1987). Many new models have been added, such as calanoid copepods like Acartia tonsa or harpacticoid copepods like Nitocra spinipes, Tisbe battagliai and especially several species of Tigriopus (Figure 15.1e). The malacostracan amphipods of the genus Corophium are commonly used and more locally the malacostracan mysid Mysidopsis bahia (Pane et al. 2012).

\subsubsection{Body Elongation and Segmentation}

The anamorphosis that occurs in several groups of crustaceans is very reminiscent of the development that can be observed in other lineages of Metazoa, such as annelids (Chapter 13). The study of Artemia as an anamorphic organism has been initiated and has yielded interesting results (Averof and Akam 1995; Copf et al. 2003; Kontarakis et al. 2006; Copf et al. 2006; Prpic 2008). The thick cuticle and the lack of a functional tool are no doubt the reason studies on this model were abandoned at the expense of Paryhale (Chapter 16). In the years to come, however, it will be necessary to try to re-develop anamorphic models in order to be able to carry out the comparison with other Metazoa, because it is probable that larval retention modifies the ontogenetic sequences and can disrupt the comparisons.

\subsubsection{Evolution of Ontogeny}

In crustaceans, embryonic development can lead to the release of a juvenile resembling the adult, as in Parhyale (Chapter 16), but in many cases, embryonic development leads to the hatching of a larva whose development will often continue in plankton. Depending on the case, the released larva will have the number of body segments of the adult (zoe-like larva) or sometimes will be reduced to the most anterior region of the head (nauplius_Figure 15.3).

The body elongation processes will therefore be larval and/ or embryonic in the different groups, with equivalent stages in both modes of development. Modalities of development largely remain to be studied. For a long time, it was believed that there was only a phenomenon of larval retention, but it seems possible that the limit of the passage between embryo and larva is more flexible and that, in particular, the nauplius larva has reappeared in malacostracans following a phenomenon of heterochrony (Jirikowski et al. 2015).

The same type of precise developmental comparison was initiated between a pseudo-direct and indirect development in branchiopods. It seems that the transition to direct development in cladocerans and cyclestherides has resulted in a modification of the ontogenetic stages with a compaction of certain stages of ancestrally anamorphic development (Fritsch et al. 2013). At the level of all crustaceans, this type of research still remains largely to be developed.

\subsubsection{Terrestrialization AND Origin Of INSECTS}

The transition from aquatic to aerial life requires profound physiological transformations, with the acquisition of important morpho-anatomical innovations affecting essential functions. This is a milestone in the history of the planet. There are several types of colonization of pancrustaceans in the aerial environment. In many decapod malacostracans, animals have retained the classic marine larval development, and therefore the adaptations to aerial life only concern juveniles and adults. There are also more colonizations with complete independence from the marine environment. The most important is undoubtedly that of the hexapods (Regier et al. 2010), but we can also cite the malacostracan amphipods and especially isopods. This last group would have colonized the mainland after the hexapods at the time of the Permian (Lins et al. 2017), but its phylogenetic history is still not understood (Dimitriou et al. 2019).

The research to be carried out concerns the acquisition of adaptations that are sometimes convergent between the lineages, such as the reduction of gill surface in different lines of land or intertidal crabs (O'Mahoney and Full 1984). The establishment of tracheae or pseudo-tracheae also appeared in a convergent manner in hexapods or malacostracan isopods (wood lice) and also elsewhere in arthropods (Cook 
et al. 2001; Csonka et al. 2013). Terrestrialization had other effects on the anatomical organization, such as the loss of lateral parts of the appendages and also the reduction of sensory structures. We can thus study the processes leading to the loss of antennas. In wood lice, terrestrialization has led to a strong reduction in A1 (Schmalfuss 1998), while in the hexapods, it is thought that it is the A2 that has entirely disappeared giving the intercalary segment. It is possible that developmental genes like col are involved in the appendage-less morphology of the intercalary segment of insects (Schaeper et al. 2010), but a comparative investigation must be carried out if similar mechanisms have been initiated following terrestrialization. To understand certain adaptations linked to terrestrial colonization, it is also possible to compare different lineages of aquatic pancrustaceans with insects to identify homologies between organs. This strategy made it possible to consider that the wings of insects could be derived from gills (Averof and Cohen 1997; Jockusch and Nagy 1997).

\subsubsection{The Emergence of Parasitic Forms}

The emergence of a parasitic lifestyle leads to profound changes in the life cycle and morpho-anatomy of organisms. In crustaceans, there are many parasitic forms, and the morpho-anatomical modifications are varied and more or less important. The case of cirripeds (Figure 15.1b) is particularly interesting because the larval stages are still very similar between the parasitic and non-parasitic forms. In this case, it is the metamorphosis from the cypris that is the key step in understanding the change in lifestyle (Høeg and Møller 2006) (Figure 15.4c). A detailed comparison of metamorphosis should make it possible to propose homologies between the post-metamorphosis stages and better understand the transformations in the lineages. It has already been identified that in Sacculina carcini, the naupliar stages are entirely lecitotrophic and synchronous, which is not the case in non-parasitic forms (Trédez et al. 2016) and suggests that there are therefore already modifications even before the cyprid stage.

\subsubsection{Evolution of Cryptobiosis}

Cryptobiosis is a very practical phenomenon for obtaining larvae at the right time (Figure 15.6), but the embryo in this suspended state of life is also a remarkable object of study. The brine shrimp is one of the three major models in this field, with nematodes and tardigrades (Hibshman et al. 2020). Several axes of research emerge from this problem: the formation of the shell of the resting eggs, the synthesis of trehalose, metabolic modifications with the synthesis of specific molecules such as Artemin, small Heat Shock proteins and late embryogeneisis abundant (LEA) proteins (Hibshman et al. 2020). Additionally, the structure of the particularly porous eggshell appears to be a carrier for nanocomposite material preparation and catalytic materials, opening up studies for new applied research (Wang et al. 2015; Zhao et al. 2019).
On the other hand, there is high variability in the shape and ornamentation of resting eggs among branchiopods (Figure 15.8). In particular, there are spherical, lenticular, tetrahedral or cylindrical shapes with a smooth, wrinkled or thorny surface (Figure 15.8) (Gilchrist 1978; Brendonck et al. 1992; Thiéry et al. 2007; Rabet 2010). A mathematical approach to these objects has already made it possible to understand that in Tanymastix stagnalis, the general shape is lenticular (Figure 15.8b) and corresponds to the intersection between two spheres. However, another shape can also be observed and would correspond to the intersection between two cylinders. In this case, the change in embryo shape would be due to an increase in volume (Thiéry et al. 2007). There are still many unanswered questions about the mechanisms allowing the construction of these shells and understanding how symmetry is acquired.

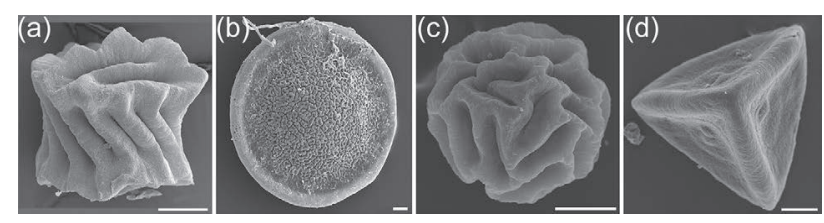

FIGURE 15.8 Variation of the resting egg shape in branchiopods. (a) Cylindrical, Eulimnadia cylindrova; (b) lenticular, Tanymastix affinis; (c) spherical, Eulimnadia diversa; (d) tetrahedral, Streptocephalus archeri.

\section{BIBLIOGRAPHY}

Abele, L.G., Kim, W. and B.E. Felgenhauer. 1989. Molecular evidence for inclusion of the phylum Pentastomida in the Crustacea. Molecular Biology and Evolution. 6:685-691.

Abramova, A., Lind, U., Blomberg, A. and M.A. Rosenblad. 2019. The complex barnacle perfume: Identification of waterborne pheromone homologues in Balanus improvisus and their differential expression during settlement. Biofouling. 35 (4):416-428.

Adamczewska, A.M. and S. Morris. 2001. Ecology and behavior of Gecarcoidea natalis, the Christmas Island Red Crab, during the annual breeding migration. The Biological Bulletin. 200:305-320.

Addis, A., Fabiano, F., Delogu, V. and M. Carcupino. 2012. Reproductive system morphology of Lightiella magdalenina (Crustacea, Cephalocarida): Functional and adaptive implications. Invertebrate Reproduction and Development. 57 (2):142-155.

Ahyong, S.T., Lowry, J.K. Alonso, M., Bamber, R.N., Boxshall, G.A., Castro, P., Gerken, S. et al. 2011. Subphylum Crustacea Brünnich, 1772. In: Zhang, Z.-Q. (Ed.), Animal biodiversity: An outline of higher-level classification and survey of taxonomic richness. Zootaxa. 3148:165-191.

Alekseev, V. and Y.I. Starobogatov. 1996. Types of diapause in Crustacea: Definitions, distribution, evolution. Hydrobiologia. 320 (1):15-26.

Alexeeva, N., Bogomolova, E., Tamberg, Y. and N. Shunatova. 2017. Oligomeric larvae of the pycnogonids revisited. Journal of Morphology. 278:1284-1304.

Alfsnes, K., Leinaas, H.P. and D.O. Hessen. 2017. Genome size in arthropods: Different roles of phylogeny, habitat and life history in insects and crustaceans. Ecology and Evolution. 7:5939-5947. 
Anderson, D.T. 1967. Larval development and segment formation in the branchiopod crustaceans Limnadia stanleyana King (Conchostraca) and Artemia salina (L.)(Anostraca). Australian Journal of Zoology. 15:47-91.

Anderson, E., Lochhead, J.H., Lochhead, M.S., and E. Huebner. 1970. The origin and structure of the tertiary envelope in thick-shelled eggs of the brine shrimp, Artemia. Journal of Ultrastructure and Molecular Structure Research. 525:497-525.

Anger, K. 2001. The Biology of Decapod Crustacean Larvae. Publisher: A.A. Balkema. Boca Raton, FL: CRC Press.

Averof, M. and M. Akam. 1995. Hox genes and the diversification of insect and crustacean body plans. Nature. 376 (6539):420-423.

Averof, M. and S.M. Cohen. 1997. Evolutionary origin of insect wings from ancestral gills. Nature. 385:627-630.

Averof, M. and N.H. Patel. 1997. Crustacean appendage evolution associated with changes in Hox gene expression. Nature. 388 (6643):682-686.

Baldwin-Brown, J.G., Weeks S.C. and A.D. Long. 2017. A new standard for crustacean genomes: The highly contiguous, annotated genome assembly of the clam shrimp Eulimnadia texana reveals Hox gene order and identifies the sex chromosome. Genome Biology and Evolution. 10 (1):143-156.

Barazandeh, M., Davis, C.S., Neufeld, C.J., Coltman, D.W. and A.R. Palmer. 2013. Something Darwin didn't know about barnacles: Spermcast mating in a common stalked species. Proceedings of the Royal Society B. 280:20122919.

Barreto, F.S., Watson, E.T., Lima, T.G., Willett, C.S., Edmands, S., Li, W. and R.S. Burton. 2018. Genomic signatures of mitonuclear coevolution across populations of Tigriopus californicus. Nature Ecology \& Evolution. 2 (8):1250-1257.

Bauer R.T. 2013. Amphidromy in shrimps: A life cycle between rivers and the sea. Latin American Journal of Aquatic Research. 41 (4):633-650.

Benesch, R. 1969. Zur Ontogenie und Morphologie von Artemia salina L. Zoologische Jahrbücher. Abteilung für Anatomie und Ontogenie der Tiere Abteilung für Anatomie und Ontogenie der TiereS.:307-458.

Bentov, S., Aflalo, E.D., Tynyakov, J., Glazer, L. and A. Sagi. 2016. Calcium phosphate mineralization is widely applied in crustacean mandibles. Scientific Reports. 6:22118.

Benvenuto, C. and S.C. Weeks. 2020. Hermaphroditism and gonochorism. In "The Natural History of the Crustacea: Reproductive Biology": The Natural History of the Crustacea (6). Oxford: Oxford University Press.

Bixler, G.D. and B. Bhushan. 2012. Biofouling: Lessons from nature. Philosophical Transactions of the Royal Society. A370: 2381-2417.

Blin, M., Rabet, N., Deutsch, J., and Mouchel-Vielh, E. 2003. Possible implication of Hox genes abdominal-B and abdominal- $A$ in the specification of genital and abdominal segments in cirripedes. Development Genes and Evolution 213:90-96.

Bowen, S.T., Durkin, J.P., Sterling, G., and L.S. Clark. 1978. Artemia hemoglobins: Genetic variation in parthenogenetic and zygogenetic populations. Biological Bulletin, 155 (2):273-287.

Bowman, T.E. and L.G. Abele. 1982. Classification of the recent Crustacea. In Systematics, the Fossil Record, and Biogeography, ed. Abele, L.G. (pp. 1-27). New York: Academic Press.

Boxshall, G.A. 2004. The evolution of arthropod limbs. Biological Reviews. 79 (2):253-300.

Brendonck, L., Hamer, M. and A. Thiery. 1992. Occurrence of tetrahedral eggs in the streptocephalidae daday (Branchiopoda: Anostraca) with descriptions of a new subgenus, Parastreptocephalus, and a new species, Streptocephalus
(Parastreptocephalus) zuluensis Brendonck and Hamer. Journal of Crustacean Biology. 12 (2):282-297.

Brendonck, L., Rogers, D.C., Olesen, J., Weeks, S. and W.R. Hoeh. 2008. Global diversity of large branchiopods (Crustacea: Branchiopoda) in freshwater. Hydrobiologia. 595 (1):167-176.

Browne, W.E., Price, A.L., Gerberding, M. and N.H. Patel. 2005. Stages of embryonic development in the amphipod crustacean, Parhyale hawaiensis. Genesis. 42 (3):124-149.

Brünnich, M.T. 1772. Zoologiae fundamenta praelectionibus academicis accommodata: Grunde i Dyrelaeren. Hafniae et Lipsiae: Apud Frider. Christ. Pelt.

Calman, W.T. 1909. Crustacea. In A Treatise on Zoology, Part 7, Fascicle 3, ed. Lankester, E.R.(pp. 1-346). London: Adam and Charles Black.

Carere, C., Nascetti, G., Carlini A., Santucci D. and E. Alleva. 2015. Actions for restocking of the European lobster (Homarus gammarus): A case study on the relevance of behaviour and welfare assessment of cultured juveniles. Rendiconti Lincei. Scienze Fisiche e Naturali. 26:59-64.

Charnov, E.L. 1987. Sexuality and hermaphroditism in barnacles: A natural selection approach. In Barnacle Biology, Crustacean Issues 5, ed. Southward, A.J. (pp. 89-103). Rotterdam: A. A. Belkema, Rotterdam.

Chebbi, M.A., Becking, T., Moumen, B., Giraud, I., Gilbert, C., Peccoud, J. and R. Cordaux. 2019. The genome of Armadillidium vulgare (Crustacea, Isopoda) provides insights into sex chromosome evolution in the context of cytoplasmic sex determination. Molecular Biology and Evolution. 36 (4): 727-741.

Colbourne, J.K., Pfrender, M.E., Gilbert, D., Thomas, W.K., Tucker, A., Oakley, T.H., Tokishita, S., Aerts, A., Arnold, G.J., Kumar Basu, M., Bauer, D.J., Cáceres, C.E., Carmel, L., Casola, C., Choi, J.-H., Detter, J.C., Dong, Q., Dusheyko, S., Eads, B.D., Fröhlich, T., Geiler-Samerotte, K.A., Gerlach, D., Hatcher, P., Jogdeo, S., Krijgsveld, J., Kriventseva, E.V., Kültz, D., Laforsch, C., Lindquist, E., Lopez, J., Manak, J.R., Muller, J., Pangilinan, J., Patwardhan, R.P., Pitluck S., Pritham, E.J., Rechtsteiner A., Rho, M., Rogozin, I.B., Sakarya, O., Salamov, A., Schaack, S., Shapiro, H., Shiga, Y., Skalitzky, C., Smith, Z., Souvorov, A., Sung, W., Tang, Z., Tsuchiya, D., Tu, H., Vos, H., Wang, M., Wolf, Y.I., Yamagata, H., Yamada T., Ye, Y., Shaw, J.R., Andrews, J., Crease, T.J., Tang, H., Lucas, S.M., Robertson, H.M., Bork, P., Koonin, E.V., Zdobnov, E.M., Grigoriev, I.V., Lynch, M. and J.L. Boore. 2011. The ecoresponsive genome of Daphnia pulex. Science. 331:555-561.

Collette, J.H. and J.W. Hagadorn. 2010. Early evolution of phyllocarid arthropods: Phylogeny and systematics of Cambrian-Devonian archaeostracans. Journal of Paleontology. 84 (5):795-820.

Collis, S.A. and G. Walker. 1994. The morphology of the naupliar stages of Sacculina carcini (Crustacea: Cirripedia: Rhizocephala). Acta Zoologica. 75 (4):297-303.

Cook, C.E., Smith, M.L., Telford, M.J., Bastianello, A. and M. Akam. 2001. Hox genes and the phylogeny of the arthropods. Current Biology. 11 (10):759-763.

Copf, T., Rabet, N. and M. Averof. 2006. Knockdown of spalt function by RNAi causes de-repression of Hox genes and homeotic transformations in the crustacean Artemia franciscana. Developmental Biology. 298 (1):87-94.

Copf, T., Rabet, N., Celniker, S.E. and M. Averof. 2003. Posterior patterning genes and the identification of a unique body region in the brine shrimp Artemia franciscana. Development. 130 (24):5915-5927.

Copf, T., Schröder, R. and M. Averof. 2004. Ancestral role of caudal genes in axis elongation and segmentation. Proceedings of the National Academy of Sciences. 101 (51):17711-17715. 
Csonka, D., Halasy, K., Szabó, P., Mrak, P., Štrus, J. and E. Hornung. 2013. Eco-morphological studies on pleopodal lungs and cuticle in Armadillidium species (Crustacea, Isopoda, Oniscidea). Arthropod Structure and Development. 42:229-235.

Dabrowski, K. and M. Miller. 2018. Contested paradigm in raising zebrafish (Danio rerio). Zebrafish. 15 (3):295-309.

Dahms, H.-U. 2000. Phylogenetic implications of the Crustacean nauplius. Hydrobiologia. 417:91-99.

Delage, Y. 1884. Évolution de la Sacculine (Sacculina carcini Thomps.): crustacé endoparasite de l'ordre nouveau des Kentrogonides. Archives de zoologie expérimentale et générale. 2:417-736.

Desai, D.V., Anil, A.C. and K. Venkat. 2006. Reproduction in Balanus amphitrite Darwin (Cirripedia: Thoracica): Influence of temperature and food concentration. Marine Biology. 149:1431-1441.

Dimitriou, A.C., Taiti S. and S. Sfenthourakis. 2019. Genetic evidence against monophyly of Oniscidea implies a need to revise scenarios for the origin of terrestrial isopods. Scientific Reports. 9 (1): 18508.

Dohle, W. 2001. Are the insects terrestrial crustaceans? A discussion of some new facts and arguments and the proposal of the proper name 'Tetraconata' for the monophyletic unit Crustacea + Hexapoda. In: Deuve, T. (ed.) Origin of the Hexapoda. Annales de la Société entomologique de France (N.S.). 37:85-103.

Duffy, E. 1996. Eusociality in a coral-reef shrimp. Nature. 381 (6582):512-514.

Durbin, A.P., Hebert, D.N. and M.E.A. Cristescu. 2008. Comparative phylogeography of marine cladocerans. Marine Biology. 155:1-10.

Escobedo-Bonilla, C.M. 2011. Application of RNA interference (RNAi) against viral infections in shrimp. Journal of Antivirals \& Antiretrovirals. S9.

FAO. 2020. The State of World Fisheries and Aquaculture 2020: Sustainability in Action. Rome. https://doi.org/10.4060/ ca9229en

Fraser J.H. 1936. The occurrence, ecology and life history of Tigriopus fulvus (Fischer). Journal of the Marine Biological Association of the United Kingdom. 20 (3):523-536.

Fritsch, M., Bininda-Emonds, O.R.P. and S. Richter. 2013. Unraveling the origin of Cladocera by identifying heterochrony in the developmental sequences of Branchiopoda. Frontiers in Zoology. 10 (1):35.

Fryer, G.F.L.S. 1996. Diapause, a potent force in the evolution of freshwater crustaceans. Hydrobiologia. 320:1-14.

Gajardo, G. and J.A. Beardmore. 2012. The brine shrimp Artemia: Adapted to critical life conditions. Frontiers in Zoology. 3:185.

Garreau de Loubresse, N. 1974. Etude chronologique de la mise en place des enveloppes de l'œuf d'un crustacé phyllopode, Tanymastix lacunae. Journal of Microscopy. 20:21-38.

Gibert, J.M., Mouchel-Vielh, E., Quéinnec, E and J.S. Deutsch. 2000. Barnacle duplicate engrailed genes: Divergent expression patterns and evidence for a vestigial abdomen. Evolution and Development. 2:194-202.

Gilchrist, B.M. 1978. Scanning electron microscope studies of the egg shell in some anostraca (Crustacea: Branchiopoda). Cell and Tissue Research. 193:337-351.

Giribet, G. and G.D. Edgecombe. 2019. The phylogeny and evolutionary history of Arthropods. Current Biology. 29 (12):R592-R602.

Gong, Yi and Xiaobo Zhang. 2021. RNAi-based antiviral immunity of shrimp: Review. Developmental and Comparative Immunology. 115:103907.
Gurney, R. 1942. Larvae of Decapod Crustacea. London: Ray Society.

Gutekunst, J., Andriantsoa, R., Falckenhayn, C., Hanna, K., Stein, W., Rasamy, J. and F. Lyko. 2018. Clonal genome evolution and rapid invasive spread of the marbled crayfish. Nature Ecology \& Evolution. 2:567-573.

Gutiérrez-Zugasti, I. 2011. The use of echinoids and crustaceans as food during the Pleistocene-Holocene transition in Northern Spain: Methodological contribution and dietary assessment. The Journal of Island and Coastal Archaeology. 6 (1):115-133.

Hibshman, J.D., Clegg, J.S. and B. Goldstein. 2020. Mechanisms of desiccation tolerance: Themes and variations in brine shrimp, roundworms, and tardigrades. Frontiers in Physiology. 11:592016.

Høeg, J.S. and J. Lützen. 1995. Life cycle and reproduction in the Cirripedia Rhizocephala. Oceanography and Marine Biology: An Annual Review. 33:427-485.

Høeg, J.T. and O.S. Møller. 2006. When similar beginnings lead to different ends: Constraints and diversity in cirripede larval development. Invertebrate Reproduction and Development. 49 (3):125-142.

Hudinaga, M. 1942. Reproduction, development and rearing of Penaeus japonicus Bate. Japanese Journal of Environmental Entomology and Zoology. 10:305-393.

Jensen, G.C., Sean McDonald, P. and D.A. Armstrong. 2007. Biotic resistance to green crab, Carcinus maenas, in California bays. Marine Biology. 151:2231-2243.

Jeong, C.B., Lee, B.Y., Choi, B.S., Kim, M.S., Park, J.C., Kim, D.-H., Wang M. et al. 2020. The genome of the harpacticoid copepod Tigriopus japonicus: Potential for its use in marine molecular ecotoxicology. Aquatic Toxicology. 222:105462.

Jin, S., Bian, C., Jiang, S., Han, K., Xiong, Y., Zhang, W., Shi, C. et al. 2021. A chromosome-level genome assembly of the oriental river prawn, Macrobrachium nipponense. GigaScience. 10:1-9.

Jirikowski, G.J., Richter, S. and C. Wolff. 2013. Myogenesis of Malacostraca: The "egg-nauplius" concept revisited. Frontiers in Zoology. 10:76.

Jirikowski, G.J., Wolff, C. and S. Richter. 2015. Evolution of eumalacostracan development: New insights into loss and reacquisition of larval stages revealed by heterochrony analysis. EvoDevo. 6:4.

Jockusch, E.L. and L.M. Nagy. 1997. Insect evolution: How did insect wings originate? Current Biolology. 7 (6):R358-R361.

Jonsson, P.R., Wrange, A.L., Lind, U., Abramova, A., Ogemark, M. and A. Blomberg. 2018. The barnacle Balanus improvisus as a marine model: Culturing and gene expression. Journal of Visualized Experiments. (138):e57825.

Jørgensen, S., B. Lykke, H. Nielsen, et al. 2019a. The whole genome sequence and mRNA transcriptome of the tropical cyclopoid copepod Apocyclops royi. G3: Genes, Genomes, Genetics. 9 (5):1295-1302.

Jørgensen, T.S., Petersen, B., Petersen, H.C.B., et al. 2019b. The genome and mRNA transcriptome of the cosmopolitan calanoid copepod Acartia tonsa Dana improve the understanding of copepod genome size evolution. Genome Biology and Evolution. 11 (5):1440-1450.

Kang, S., Ahn, D.-H., Lee, J.H., Lee, S.G., Shin, S.C., Lee, J., et al. 2017. The genome of the Antarctic-endemic copepod, Tigriopus kingsejongensis. GigaScience. 6:1-9.

Kao, D., Lai, A.G., Stamataki, E., Rosic, S., Konstantinides, N., Jarvis, E., Di Donfrancesco, et al. 2016. The genome of the crustacean Parhyale hawaiensis, a model for animal development, regeneration, immunity and lignocellulose digestion. Elife. 5:e20062. 
Kato, Y., Matsuura, T. and H. Watanabe. 2012. Genomic integration and germline transmission of plasmid injected into crustacean Daphnia magna eggs. PLoS One. 7 (9):e45318.

Kawai, T., Scholtz, G., Morioka, S., Ramanamandimby, F., Lukhaup, C. and Y. Hanamura. 2009. Parthenogenetic alien crayfish (Decapoda: Cambaridae) spreading in Madagascar. Journal of Crustacean Biology. 29 (4):562-567.

Kenny, N.J., Sin, Y.W., Shen, X., Zhe, Q., Wang, W., Chan, T.F., Tobe, S.S., et al. 2014. Genomic sequence and experimental tractability of a new decapod shrimp model, Neocaridina denticulate. Marine Drugs. 12:1419-1437.

Kim, D.-H., Choi, B.-S., Kang, H.-M., Park, J.C., Kim, M.-S., Hagiwara, A. and J.-S. Lee. 2021. The genome of the marine water flea Diaphanosoma celebensis: Identification of phase I, II, and III detoxification genes and potential applications in marine molecular ecotoxicology. Comparative Biochemistry and Physiology Part D: Genomics and Proteomics. 37:100787.

Kim, J.-H., Kim, H.K., Chan, K.H., BKK, Kang, S. and W. Kim. 2019. Draft genome assembly of a fouling barnacle, Amphibalanus amphitrite (Darwin, 1854): The first reference genome for Thecostraca. Frontiers in Ecology and Evolution. 7:465.

Kobayashi, H., Hatada, Y., Tsubouchi, T., Nagahama, T. and H. Takami. 2012. The hadal Amphipod Hirondellea gigas possessing a unique cellulase for digesting wooden debris buried in the deepest seafloor. PLoS One. 7(8):e42727.

Kobayashi, H., Shimoshige, H., Nakajima, Y., Arai, W. and H. Takami. 2019. An aluminum shield enables the amphipod Hirondellea gigas to inhabit deep-sea environments. PLoS One. 14 (4): 0206710.

Koenemann, S., Schram, F.R., Iliffe, T.M., Hinderstein, L.M. and A. Bloechl. 2007. Behavior of remipedia in the laboratory, with supporting field observations. Journal of Crustacean Biology. 27:534-542.

Kontarakis, Z., Copf, T. and M. Averof. 2006. Expression of hunchback during trunk segmentation in the branchiopod crustacean Artemia franciscana. Development Genes and Evolution. 216 (2):89-93.

Korn, M. and A.K. Hundsdoerfer. 2016. Molecular phylogeny, morphology and taxonomy of Moroccan Triops granarius (Lucas, 1864) (Crustacea: Notostraca), with the description of two new species. Zootaxa. 4178 (3):328-346.

Krieger, J., Sandeman, R.E., Sandeman, D.C., Hansson, B.S. and S. Harzsch. 2010. Brain architecture of the largest living land arthropod, the giant robber crab Birgus latro (Crustacea, Anomura, Coenobitidae): Evidence for a prominent central olfactory pathway? Frontiers in Zoology. 7:25.

Krishnan, P., Gireesh-Babu, P., Rajendran, K.V. and A. Chaudhar. 2009. RNA interference-based therapeuticsfor shrimp viral diseases. Aquatic Organisms. 86:263-272.

Laubier, A. and L. Laubier. 1993. Marine crustacean farming: Present status and perspectives. Aquatic Living Resources. 6 (4):319-329.

Lavrov, D.V., Brown, W.M. and J.L. Boore. 2004. Phylogenetic position of the Pentastomida and (pan)crustacean relationships. Proceedings of the Royal Society B: Biological Sciences. 271:537-544.

Lechable, M., Jan, A., Duchene, A., Uveira, J., Weissbourd, B., Gissat, L., Collet, S., et al. 2020. An improved whole life cycle culture protocol for the hydrozoan genetic model Clytia hemisphaerica. Open Biology. 9 (11):bio051268.

Lee, B.-Y., Choi, B.-S., Kim, M.-S., Park, J.C., Jeong, C.-B., Han, J. and J.-S. Lee. 2019. The genome of the freshwater water flea Daphnia magna: A potential use for freshwater molecular ecotoxicology. Aquatic Toxicology. 210:69-84.
Lee, M.S.Y., Soubrier, J. and G.D. Edgecombe. 2013. Rates of phenotypic and genomic evolution during the Cambrian explosion. Current Biology. 23:1889-1895.

Liang, C., Strickland, J., Ye, Z., Wu, W., Hu, B. and D. Rittschof. 2019. Biochemistry of barnacle adhesion: An updated review. Frontiers in Marine Science. 6:2296-7745.

Lindley, J.A. 1997. Eggs and their incubation as factors in the ecology of planktonic crustacea. Journal of Crustacean Biolology. 17 (4):569-576.

Linnaeus, C. von. 1758. Caroli Linnaei Equitis De Stella Polari, Archiatri Regii, Med. \& Botan. Profess. Upsal.; Systema Naturae Per Regna Tria Naturae, Secundum Classes, Ordines, Genera, Species, Cum Characteribus, Differentiis, Synonymis, Locis, Holmiae.

Lins, L.S.F., Ho, S.Y.W. and N. Lo. 2017. An evolutionary timescale for terrestrial isopods and a lack of molecular support for the monophyly of Oniscidea (Crustacea: Isopoda). Organisms Diversity and Evolution. 17:813-820.

Liu, Y.-L., Zhao, Y., Dai, Z.-M., Chen, H.-M., and W.-J. Yang. 2009. Formation of diapause cyst shell in brine shrimp, Artemia parthenogenetica, and its resistance role in environmental stresses. The Journal of Biological Chemistry. 284 (25):16931-16938.

Lohse, D., Schmitz, B. and M. Versluis. 2001. Snapping shrimp make flashing bubbles. Nature. 413 (6855):477-478.

Lowenstam, H.A. and S. Weiner. 1992. Phosphatic shell plate of the barnacle Ibla (Cirripedia): A bone-like structure. Proceedings of the National Academy of Sciences. 89 (22):10573-10577.

Madhu, R., Madhu, K. and T. Retheesh. 2012. Life history pathways in false clown Amphiprion ocellaris Cuvier, 1830: A journey from egg to adult under captive condition. Journal of the Marine Biological Association of India. 54 (1):77-90.

Maier, G. 1992. Metacyclops minutus (Claus, 1863): Population dynamics and life history characteristics of a rapidly developing copepod. International Review of Hydrobiology. 77: 455-466.

Malitan, H.S., Cohen, A.M. and T.H. MacRae. 2019. Knockdown of the small heat-shock protein p26 by RNA interference modifies the diapause proteome of Artemia franciscana. Biochemistry and Cell Biology. 97(4):471-479.

Manzanares, M., Marco, R. and R. Garesse. 1993. Genomic organization and developmental pattern of expression of the engrailed gene from the brine shrimp Artemia. Development 118:1209-1219.

Martin, J.W. and G.E. Davis. 2001. An updated classification of the recent Crustacea. Natural History Museum of Los Angeles County Contributions in Science. 39:1-124.

Martin, J.W., Olesen, J. and J.T. Høeg. 2014. The Crustacean Nauplius in Atlas of Crustacean Larvae, ed. Martin, J.W., Olesen, J. and J.T. Høeg. Baltimore, MD: Johns Hopkins University Press.

Maruzzo, D., Aldred, N., Clare, A.S. and J.T. Høeg. 2012. Metamorphosis in the cirripede crustacean Balanus amphitrite. PLoS One. 7 (5):e37408.

Mayrat, A. and M. de Saint Laurent. 1996. Considérations sur la Classe de Malacostracés. (Malacostraca Latreille, 1802). In Traité de zoologie, ed. GrasséÉ, P.-P. and J. Forest. (pp. 841862). Masson, Paris: Crustacea.

McLaughlin, P.A. 1980. Comparative Morphology of Recent Crustacea. San Francisco: W. H. Freeman and Company. [General crustacean morphology].

Monod, T. and J. Forest. 1996. Histoire de la classification des Crustacés, Traité de zoologie, Anatomie, systématique, biologie, Crustacés, Tome VII, fascicule II (pp. 235-267). Paris, Milan, Barcelone: Masson. 
Morris, J.E. and B.A. Afzelius. 1967. The structure of the shell and outer membranes in encysted Artemia salina embryos during cryptobiosis and development. Journal of Ultrastructure Research. 20 (3-4): 244-259.

Neiber, M.T., Hartke, T.R., Stemme, T., Bergmann, A., Rust, J., Iliffe, T.M. and S. Koenemann. 2011. Global biodiversity and phylogenetic evaluation of Remipedia (Crustacea). PLoS One. 6 (5):e19627.

Nesterov, O. 2018. Consideration of various aspects in a drift study of MH370 debris. Ocean Science. 14:387-402.

Olson, C.S. and J.S. Clegg. 1978. Cell division during the development of Artemia salina. Wilhelm Roux's Archives of Developmental Biology. 184:1-13.

O’Mahoney, P.M. and R.J. Full. 1984. Respiration of crabs in air and water. Comparative Biochemistry and Physiology Part A: Physiology. 79 (2):275-282.

Pabst, T. and G. Scholtz. 2009. The development of phyllopodous limbs in leptostraca and branchiopoda. Journal of Crustacean Biology. 29 (1):1-12.

Pane, L., Agrone, C., Giacco, E., Somà, A. and G.L. Mariottini. 2012. Utilization of marine crustaceans as study models: A new approach in marine ecotoxicology for European (REACH) regulation. In Ecotoxicology, ed. Begum, G. (pp. 91-106). Crotia: InTech.

Panouse, J.B. 1943. Influence de l'ablation du pédoncule oculaire sur la croissance de l'ovaire chez la crevette Leander serratus. Comptes rendus hebdomadaires des séances de l'Académie des sciences. 217:553-555.

Patek, S.N. and R.L Caldwell. 2005. Extreme impact and cavitation forces of a biological hammer: Strike forces of the peacock mantis shrimp Odontodactylus scyllarus. Journal of Experimental Biology. 208:3655-3664.

Patra, A.K., Chung, O., Yoo, J.Y., Kim, M.S., Yoon, M.G., Choi, J.-H. and Y. Yang. 2020. First draft genome for the sandhopper Trinorchestia longiramus. Scientific Data. 7 (1):85.

Pennak, R.W. and D.J. Zinn. 1943. Mystacocarida, a new order of Crustacea from intertidal beaches in Massachusetts and Connecticut. Smithsonian Miscellaneous Collections. 103 (9):1-11, pls.1-2.

Persoone, G. and P.G. Wells. 1987. Artemia in aquatic toxicology: A review. Artemia Research and Its Applications. 1:259-275.

Petersen, J., Ramette, M.A., Lott C., Cambon-Bonavita, M.A., Zbinden, M. and N. Dubilier. 2010. Dual symbiosis of the vent shrimp Rimicaris exoculata with filamentous gammaand epsilonproteobacteria at four Mid-Atlantic Ridge hydrothermal vent fields. Environmental Microbiology. 12 (8): 2204-2218.

Prpic, N.-M. 2008. Parasegmental appendage allocation in annelids and arthropods and the homology of parapodia and arthropodia. Frontiers in Zoology. 5:17.

Rabet, N. 2010. Revision of the egg morphology of Eulimnadia (Crustacea, Branchiopoda, Spinicaudata). Zoosystema 32 (3):373-391.

Rabet, N., Gibert, J.M., Quéinnec, E., Deutsch, J.S. and E. MouchelVielh. 2001. The caudal gene of the barnacle Sacculina carcini is not expressed in its vestigial abdomen. Development Genes and Evolution. 211:172-178.

Raisuddin, S., Kwok, K.W.H., Leung, K.M.Y., Schlenk, D. and J.-S. Lee. 2007. The copepod Tigriopus: A promising marine model organism for ecotoxicology and environmental genomics. Aquatic Toxicology. 83 (3):161-173.

Rajitha, K., Nancharaiaha, Y.V. and V.P. Venugopalan. 2020. Insight into bacterial biofilm-barnacle larvae interactions for environmentally benign antifouling strategies. International Biodeterioration \& Biodegradation. 149:104937.
Rees, D.J., Dufresne, F., Glémet H. and C. Belzile. 2007. Amphipod genome sizes: First estimates for arctic species reveal genomic giants. Genome. 50 (2):151-158.

Regier, J.C., Jeffrey, W.S. and R.E. Kambic. 2005. Pancrustacean phylogeny: Hexapods are terrestrial crustaceans and maxillopods are not monophyletic. Proceedings of the Royal Society B. 272:395-401.

Regier, J.C., Shultz, J.W., Zwick, A., Hussey, A., Ball, B., Wetzer R., Martin, J.W. and C.W. Cunningham. 2010. Arthropod relationships revealed by phylogenomic analysis of nuclear protein-coding sequences. Nature. 463 (7284):1079-1083.

Richter, S. 2002. The Tetraconata concept: Hexapod-crustacean relationships and the phylogeny of Crustacea. Organisms Diversity and Evolution. 2:217-237.

Riley, J., Banaja, A.A. and J.L. James. 1978. The phylogenetic relationships of the Pentastomida: The case for their inclusion within the Crustacea. International Journal for Parasitology. 8 (4):245-254.

Robalino, J., Browdy, C.L., Prior, S., Metz, A., Parnell, P., Gross, P. and G. Warr. 2004. Induction of antiviral immunity by double-stranded RNA in a marine invertebrate. Journal of Virology. 78 (19):10442-10448.

Rosowski, J.R., Belk D., Gouthro, M.A. and K.W. Lee. 1997. Ultrastructure of the cyst shell and underlying membranes of the brine shrimp Artemia franciscana Kellogg (Anostraca) during postencystic development, emergence, and hatching. Journal of Shellfish Research. 16 (1):233-249.

Sagi, A., Manor, R. and T. Ventura. 2013. Gene silencing in crustaceans: From basic research to biotechnologies. Genes. 4: 620-645.

Sanders, H.L. 1955. The Cephalocarida, a new subclass of Crustacea from Long Island Sound. Proceedings of National Academy of Sciences of the United States of America. 41 (1):61-66.

Savojardo, C., Luchetti, A., Martelli, P.L., Casadio, R. and B. Mantovani. 2019. Draft genomes and genomic divergence of two Lepidurus tadpole shrimp species (Crustacea, Branchiopoda, Notostraca). Molecular Ecology Resources. 19 (1):235-244.

Scanabissi, F. and C. Mondini. 2002. A survey of the reproductive biology in Italian branchiopods. Hydrobiologia. 486 (1):263-272.

Schaeper, N.D., Pechmann, M., Damen, W.G.M., Prpic, N.M. and E.A. Wimmer. 2010. Evolutionary plasticity of collier function in head development of diverse arthropods. Developmental Biology. 344 (1):363-376.

Schmalfuss, H. 1998. Evolutionary strategies of the antennae in terrestrial Isopods. Journal of Crustacean Biology. 18 (1):10-24.

Scholtz, G. 2002. Evolution of the nauplius stage in malacostracan crustaceans. Journal of Zoological Systematics and Evolutionary Research. 38 (3):175-187.

Scholtz, G., Braband, A., Tolley, L., Reimann, A., Mittmann, B., Lukhaup, C., Steuerwald, F. and G. Vogt. 2003. Parthenogenesis in an outsider crayfish. Nature. 421:806.

Scholtz, G. and G.D. Edgecombe, 2006. The evolution of arthropod heads: reconciling morphological, developmental and palaeontological evidence. Development Genes and Evolution. 216:395-415.

Schrehardt, A. 1987. A scanning electron-microscope study of the post-embryonic development of Artemia. In Artemia Research and Its Applications. Vol. 1: Morphology, Genetics, Strain Characterisation, Toxicology, ed. Sorgeloos, P., Bengtson, D.A., Decleir, W. and E. Jaspers (pp. 5-32). Wetteren, Belgium: Universa Press.

Schwentner, M., Combosch, D.J., Pakes, J.N., and G. Giribet. 2017. A phylogenomic solution to the origin of insects by resolving 
Crustacean-Hexapod relationships. Current Biology. 27 (12):1818-1824.

Seale, A. 1933. Brine shrimp (Artemia) as a satisfactory live food for fishes. Transactions of the American Fisheries Society. 63:129-130.

Shi, L., Yi, S., and Y. Li. 2018. Genome survey sequencing of red swamp crayfish Procambarus clarkia. Molecular Biology Reports. 45 (5):799-806.

Shima, A. and H. Mitani. 2004. Medaka as a research organism: Past, present and future. Mechanisms of Development. 121 (7-8):599-604.

Song, L., Bian, C., Luo, Y., Wang, L., You, X., Li, J., Qiu, Y., et al. 2016. Draft genome of the Chinese mitten crab, Eriocheir sinensis. Gigascience. 5:5.

Sorgeloos, P. 1980. The use of the brine shrimp Artemia in aquaculture. In The Brine Shrimp Artemia. Vol. 3. Ecology, Culturing, Use in Aquaculture, ed. Persoone, G., Sorgeloos, P., Roels, O. and E. Jaspers (p. 456). Wetteren, Belgium: Universa Press.

Stentiford, G.D., Neil, D.M., Peeler, E.J., Shields, J.D., Small, H.J., Flegel, T.W., Vlak, J.M., et al. 2012. Disease will limit future food supply from the global crustacean fishery and aquaculture sectors. Journal of Invertebrate Pathology. 110:141-157.

Tang, B., Zhang, D., Li, H., Jiang, S., Zhang, H., Xuan, F., Ge, B., et al. 2020. Chromosome-level genome assembly reveals the unique genome evolution of the swimming crab (Portunus trituberculatus). GigaScience. 9:1-10.

Thiéry, A., Rabet, N. and G. Nève. 2007. Models for intraspecific resting egg shape variation in a freshwater fairy shrimp Tanymastix stagnalis (L., 1758) (Crustacea, Branchiopoda). Biological Journal of the Linnean Society. 90 (1):55-60.

Thompson, J.V. 1836. Natural history and metamorphosis of an anomalous crustaceous parasite of Carcinus maenas, the Sacculina carcini. Entomological Magazine. 3:452-456.

Trédez, F., Rabet, N., Bellec, L. and F. Audebert. 2016. Synchronism of naupliar development of Sacculina carcini Thompson, 1836 (Pancrustacea, Rhizocephala) revealed by precise monitoring. Helgoland Marine Research. 70:26.

Van Stappen, G., Sui, L., Nguyen Hoa, V., Tamtin, M., Nyonje, B., de Medeiros Rocha, R., Sorgeloos, P. and G. Gajardo. 2019. Review on integrated production of the brine shrimp Artemia in solar salt ponds. Reviews in Aquaculture. 12:1054-1071.

von Reumont, B.M., Blanke, A., Richter, S. Alvarez, F., Bleidorn C. and R.A. Jenner. 2014. The first venomous crustacean revealed by transcriptomics and functional morphology: Remipede venom glands express a unique toxin cocktail dominated by enzymes and a neurotoxin. Molecular Biology and Evolution. 31 (1):48-58.

Waloszek, D. 1993. The upper Cambrian Rehbachiella and the phylogeny of Branchiopoda and Crustacea. Fossils and Strata. 32 (4):1-202.

Wang, S.F., Lv, F.J., Jiao, T.F., Ao, J.F., Zhang, X.C. and F.D. Jin. 2015. A novel porous carrier found in nature for nanocomposite materials preparation: A case study of Artemia egg shell-supported $\mathrm{TiO}_{2}$ for formaldehyde removal. Journal of Nanomaterials. ID 963012.

Watling, L. and M. Thiel. 2013. The crustacean carapace: Morphology, function, development, and phylogenetic history. In Book: The Natural History of the Crustacea, Vol. 1: Functional Morphology and Diversity (pp. 103-127). Chapter: Publisher: Oxford: Oxford University Press Editors.

Weeks, S.C., Brantner, J.S., Astrop, T.I., Ott, D.W. and N. Rabet. 2014. The evolution of hermaphroditism from dioecy in crustaceans: Selfing hermaphroditism described in a fourth spinicaudatan genus. Evolutionary Biology. 41:251-261.

Weydmann, A., Przyłucka, A., Lubośny, M., Walczyńska, K.S., Serrão, E.A., Pearson, G.A. and A. Burzyński. 2017. Mitochondrial genomes of the key zooplankton copepods Arctic Calanus glacialis and North Atlantic Calanus finmarchicus with the longest crustacean non-coding regions. Scientific Reports. 7: 13702.

Yager, J. 1981. A new class of Crustacea from a marine cave in the Bahamas. Journal of Crustacean Biology. 1 (3):328-333.

Zbinden, M. and M.A. Cambon-Bonavita. 2020. Rimicaris exoculata: Biology and ecology of a shrimp from deep-sea hydrothermal vents associated with ectosymbiotic bacteria. Journal Marine Ecology Progress Series. 652:187-222.

Zhao, J., Yin, J., Zhong, J., Jiao, T., Bai, Z., Wang, S., Zhang, L., et al. 2019. Facile preparation of a self-assembled Artemia cyst shell- $\mathrm{TiO}_{2}-\mathrm{MoS}_{2}$ porous composite structure with highly efficient catalytic reduction of nitro compounds for wastewater treatment. Nanotechnology. 31 (8):085603.

Zilhão, J., Angelucci, D.E., Araújo Igreja, M., Arnold, L.J., Badal, E., Callapez, P., Cardoso, et al. 2020. Last interglacial Iberian Neandertals as fisher-hunter-gatherers. Science. 367 (6485):eaaz7943.

Zrzavý, J. and P. Štys. 1997. The basic body plan of arthropods: Insights from evolutionary morphology and developmental biology. Journal of Evolutionary Biology. 10 (3):353-367.

Zucker, A. 2005. Aristote et les classifications zoologiques. Louvain-La-Neuve, Paris; Dudley, MA: Peeters. 